\title{
The European Defense Sector and EU Integration
}

\section{Jorge Silva Paulo*}

Common sense says the European integration process will not extend fully into the defense sector. This is because defense is a key pillar of state sovereignty, and the European Union (EU) has not done away with states. It is also assumed because integration within Europe is generally seen as an economic process, and defense is not something that is usually associated with the EU. In fact, as this paper shows, there is a significant level of intergovernmental cooperation already underway, and an integration process exists in the defense sector in Europe. Even at the political level, there are already meetings of EU defense ministers. So, in spite of a late start and the fact that the process may be irregular and slow, there is a path of defense integration that is already being traveled by the EU member states, a path that has been visible since 1999 .

The European integration process had security in mind at its inception-with its stated goal to end wars in Europe-by putting steel and coal (which were essential elements of arms fabrication at the time) under a supranational authority. Regulating these commodities was expected to defuse the prospect of another war between Germany and France. Security was again explicitly addressed when the member states of the European Coal and Steel Community (ECSC) signed a treaty in 1952 establishing the European Defense Community (EDC).

The EU pillar structure complicates the process of defense sector integration: the intergovernmental pillar is in place to deal with high politics ${ }^{1}$ (Common Foreign and Security Policy, CFSP); and the Community pillar exists to deal with economics, or low politics, where, in some relevant ways, the wishes of individual governments may be overridden. The intergovernmental method has the virtue of searching for consensus, so decisions tend to be more robust, while the community and integration method allows for faster decision-making processes.

However, the European integration process is far from creating a federation or a super-state, and this is even more the case in the defense sector. There is a "EuroGaullist" thesis in favor of integration and a strong Europe, in order to balance the remaining superpower (the United States). On the other hand, there is a Euro-Atlantic thesis aimed at creating a Europe that is credible in world affairs and capable of work-

* Jorge Silva Paulo is a captain in the Portuguese Navy and is currently Head of the Marine Pollution Response Service, National Maritime Authority-Portugal. He is indebted to the George C. Marshall Center for supporting his basic research during the Program of Advanced Security Studies (PASS), to General Jean-Paul Raffenne for his challenging discussions and always fruitful orientations, and to the Portuguese Navy, and VADM Luís Medeiros Alves in particular, for the opportunity to take part in the PASS course. All omissions and mistakes are the fault of the author.

1 'High politics' is an expression that was much favored by General Charles de Gaulle, for whom the term meant foreign affairs and security policy; on the other hand, 'low politics' meant mostly economic policy. 
ing alongside the U.S. ${ }^{2}$ Both views would agree that Europe is still "an economic giant, a political dwarf and a military worm." ${ }^{3}$ This paper suggests that the reason for this is that governments are accountable to their national voters, and only occasionally benefit by advancing integration or pooling sovereignty. Thus, speeches by national politicians about a strong Europe should be read as wishes, whose price is measured in critical media attention, unemployment, and short-term electoral results - which many feel is often too high a price to pay.

But the fragmentation of defense markets according to national borders has costs, referred to as the "costs of non-Europe," which were identified from the beginning of the integration process and the first days of NATO. But these costs were only given estimated values after the 1985 decision to create the Single European Market (SEM). Due to globalization, and spillover from other sectors and policies (both foreign and domestic), defense sectors can no longer be considered to be truly national. The "costs of non-Europe" influence unemployment, growth, and sovereignty, so politicians have to conduct a balancing act to mitigate their impact. The sluggish growth currently affecting many European states and the growing cost of modern weapons does not leave many options apart from moving toward integration in the defense sector, in the process accepting a clear loss of sovereignty (but hopefully compensating for the loss through pooled sovereignty). This situation presents a larger challenge for small states, because they have less industry, apart from some niche areas, and typically do not have domestic markets that are large enough to enable them to go it alone on sophisticated projects. Thus, small states either abandon their defense sectors, or they accept integration and aim at exploring economies of scale and learning through some sort of division of labor. For countries with long-standing rivalries and differences in culture, this integration in a high politics sector, such as defense, is by definition more challenging than integration in low politics sectors, such as the economy.

This paper will briefly review the history of the European integration process, with a focus on the political, economic, and legal aspects relevant to security. The following section will examine the specific aspects of the defense sector to explain why governments prefer cooperation to integration and, in cases when the latter option is chosen, states choose a slow and cautious process. The next section looks normatively to the future, offering speculation about three possible scenarios and their viability within the defense sector in five years time, considering the costs and benefits of integration for the EU. It then concludes that the EU lacks power to influence world affairs, due to a lack of capabilities and an absence of the will to obtain and make use of them. Integration would help to develop the needed capabilities, but political will is essential for the integration process itself to occur, and without a sudden change in the situation, Europeans seem to lack the will to integrate.

2 I use the designations offered by Timothy Garton Ash, in Free World (New York: Random House, 2004).

3 The phrase "economic giant and political dwarf" was used about Germany and Japan after the Second World War. 


\section{The Integration Process and the European Defense Sector}

The history of Europe since 1945 shows a path of increasing integration; it may be slow, irregular, complex, and probably irreversible, but it is remarkable what has been achieved so far. Not the least of these achievements is peace in Europe, where integration, the rule of law, and democracy are intertwined. This section describes this evolution in institutional terms, examining both the economic side of the defense sector and the institutional side, paying particular attention to one of the most talked-about and wished-for bodies of defense integration: a European armaments or defense agency.

\section{European Defense: Politics and Institutions}

Although it has roots in a distant past, the current process of integration in Europe started after World War II and the Marshall Plan, whose implementation specifically demanded that the recipient European countries would coordinate themselves in order to get aid. It began with the creation of the European Coal and Steel Community in $1951,{ }^{4}$ a new type of international organization possessing (limited) supranational powers, an integration method, and federalist ambitions, whose member states were Belgium, France, Germany, Italy, Luxembourg, and the Netherlands. Although Winston Churchill proposed European integration and was an admirer of France, he never saw the U.K. as part of the integration process, adopting the view that "we are with them, but not of them.” The U.K. and Churchill made clear their rejection of any form of European supranationality at the Congress of Europe in $1948,{ }^{5}$ to the frustration of federalists like Jean Monnet and Robert Schuman. ${ }^{6}$ The Schuman Declaration, ${ }^{7}$ which was the root from which the ECSC grew, took stock of the failure of the federalist approach, through high politics, at the Congress of Europe and tried a subtler approach to federalism through low politics (that is, economics), using the so-called community method of spillover, or engrenage. The widespread adherence to the Schuman Declaration, the French concern about the resurgence of Germany, and the Korean War ${ }^{8}$ led the federalists to believe that some steps of the integration process could be skipped, ${ }^{9}$

4 The ECSC was created by the Treaty of Paris (18 April 1951) and came into being on 1 July 1952; See Hans Schmitt, The Path to European Union: From the Marshall Plan to the Common Market (Baton Rouge: Louisiana State University Press, 1962), chapters 6-10.

5 Derek Urwin, The Community of Europe: A History of European Integration Since 1945 (London: Longman Group, 1991), 28-35.

6 The federalists believed in the Kantian Peace - that is, that a federation of democratic states would be the best system to create and maintain peace in Europe.

7 Robert Schuman was the French minister of foreign affairs, and offered this declaration in the name of his government on 9 May 1950; in fact, it was conceived by Jean Monnet, the so-called architect of European integration. Full text of the Schuman Declaration is available at http://europa.eu/abc/symbols/9-may/decl_en.htm.

8 Despite the fact that this war took place on the other side of the globe, many Europeans believed the USSR was using it as a rehearsal for its expansion in Europe.

9 Schmitt, The Path to European Union, 205-8. 
and so the Pleven Declaration ${ }^{10}$ put forward the proposal for the creation of the European Defense Community. ${ }^{11}$ This was a major milestone in European defense, ${ }^{12}$ and it is crucial to note that France was its creator; it is perhaps even more important to keep in mind that France also killed it by not ratifying the EDC Treaty. ${ }^{13}$

Although the U.K. is usually seen as the main opponent of supranational structures within Europe, the EDC is only the first of may examples of the ambivalence of France and of its political elites about any process of federal integration; ${ }^{14}$ such ambivalence and changes of course in one of the biggest states in Europe and one of its integration engines means that this process, not least in security and defense, is mostly dictated by politics and public sentiment in France. ${ }^{15}$

The collapse of the EDC forced the federalists to review their options and try to improve what worked: the community method, which operated through low politics. La

10 The Pleven Declaration, of 24 October 1950, is named after René Pleven, the French defense minister. It was a cooperative project with Jean Monnet; see Urwin, The Community of Europe, 60-68.

11

Of course, a main concern at the time was that of the future of Germany, which was not yet a sovereign state and lacked an army. A Community Army would have solved the problem of a sovereign (and potentially resurgent) Germany by having its military under supranational command. See Lord Hastings Ismay, NATO's First Five Years (Paris: NATO, 1955), ch. 4; Schmitt, The Path to European Union, 207; and Charles Zorgbibe, Histoire de la Construction Européenne (Paris: Presses Universitaires de France, 1997), 27-32.

In short, meaning the process of political integration and cooperation in the defense sector.

This Treaty of Paris was signed on 27 May 1952. When four states had already ratified it (only France and Italy were missing), the ratification process collapsed in the French National Assembly on 30 August 1954. It is important to note that one of the main concerns in 1950 that led to the Pleven Declaration, the Korean War, had stopped in July 1953.

See Margaret Blunden, "France," in The Foreign Policies of European Union Member States, ed. Ian Manners and Richard G. Whitman (Manchester: Manchester University Press, 2000), 24. For the diversity of opinion among the French elite, the examples of Aristides Briand, Charles de Gaulle, Jean Monnet, or Jacques Delors illustrate the point. Other examples of French resistance include the Fouchet Plan (1961-62), the Chaise Vide Crisis (196566); abandoning the military structure of NATO (7 March 1966); the two vetoes of the United Kingdom's membership in Communities (after applying 1961 and again in 1967); or the negative vote in the referendum on the Constitutional Treaty (2004). Not all of these were due to President de Gaulle. His motivations for vetoing the U.K. applications were twofold: one was based in high politics, because he disliked the liberal British view of the world (see Zorgbibe, Histoire de la Construction Européenne, 69-71); the other was based in low politics, because he probably believed the U.K. would oppose the CAP, his favorite EEC policy. However, this low politics view is disputed. See Andrew Moravcsik, De Gaulle and Europe: Historical Revision and Social Science Theory, Harvard University, Center for European Studies, Working Paper Series 8.5 (May 1998); and, for a contrary view, Robert Lieshout, Mathieu Segers, and Anna Vleuten, "De Gaulle, Moravcsik, and The Choice for Europe: Soft Sources, Weak Evidence,” Journal of Cold War Studies 6:4 (Fall 2004): 89139.

15 "If you want to see a country punching far above its weight class these days, look at France." Robert Kagan, “France’s Dream World,” The Washington Post (3 November 2002): B07. 
reliance Européenne came at the Messina Conference in 1957, which produced the two Treaties of Rome that created the European Economic Community (EEC) and the European Atomic Energy Community (EURATOM) ${ }^{16}{ }^{16}$ The EEC, because of its wider scope, supported and fed the integration process; however, defense was excluded from the Common Market from the start, based on Article 223 of the EEC Treaty. ${ }^{17}$ This exclusion was decades later given a limited interpretation by the Court of Justice of the European Communities (ECJ), but until then it was used by the member-states liberally, in fact excluding all goods and services even remotely related to defense from the trade and competition rules - that is, excluding them from the jurisdiction of the European Commission and the community method.

At the intergovernmental level there were also some relevant initiatives. First, the Treaty of Washington (1949) created the North-Atlantic Pact ${ }^{18}$ - a defensive alliance of Western states against the perceived threat of Soviet expansion. ${ }^{19}$ The need to improve coordination and command of military forces led to the Ottawa Convention of 1951, which gave rise to the creation of a permanent structure, the North-Atlantic Treaty Organization (NATO), with a Military Agency for Standardization, to improve standardization and interoperability between allies. Less well known (but still relevant, because of its economic and trade impact) was the Coordinating Committee for Multilateral Export Controls (COCOM), which existed outside of NATO but close to it, whose mission was to avoid exporting weapons and dual-use goods to the USSR and its allies to prevent them improving their military capability at the West's expense. ${ }^{20}$

16 The conference lasted from 1 June 1955 to 23 April 1956. The two Treaties of Rome were signed on 25 March 1957, and entered into force on 1 January 1958.

17 Article 223 of the Treaty of Rome (which established the EEC) reads:

The provisions of this Treaty shall not preclude the application of the following rules:

(a) No Member State shall be obliged to supply information the disclosure of which it considers contrary to the essential interests of its security;

(b) Any Member State may take such measures as it considers necessary for the protection of the essential interests of its security which are connected with the production of or trade in arms, munitions and war material; such measures shall not, however, adversely affect the conditions of competition in the common market regarding products which are not intended for specifically military purposes.

This prohibition was applied to the full range of military equipment and materiel, including nuclear, biological, and chemical weapons.

18 The twelve original signatories were: Belgium, Canada, Denmark, France, Iceland, Italy, Luxembourg, Netherlands, Norway, Portugal, the U.K., and the U.S. Greece and Turkey joined in 1952, and Germany in 1955; Ismay, NATO's First Five Years, ch.1.

19 Or, as its first Secretary-General, Lord Ismay, said, NATO was intended "to keep the Russians out, the Americans in, and the Germans down.” As quoted in George Robertson, “NATO Needs New Forces for New Challenges,” The Independent (U.K.) (25 July 2000); available at www.independent.co.uk/opinion/commentators/nato-needs-new-forces-for-newchallenges-709659.html.

20 Michael Lipson, “The Reincarnation of COCOM: Explaining Post-Cold War Export Controls,” The Non-Proliferation Review (Winter 1999): 33-51. 
After the Western Union was formed in $1948^{21}$ — which was still very much an alliance against Germany - another important development was the process that led to the creation of the Western European Union. The WEU included Germany and Italy and, although it placed some limitations on their sovereignty, it helped restore them to something resembling normalcy in international relations. Through the ECSC, they were already part of the economic integration process in Europe; they then entered the defense alliances, WEU and NATO, in 1955. This made sense, because the perceived threat at the time was the USSR. It should be noted that the WEU, like NATO, also had some sort of integration in mind when it created its Standing Armaments Committee, but it produced very few results, and only at the operational level, much like the WEU itself (which was almost dormant until 1984). It was mainly in the context of NATO, under the leadership of the United States, that security cooperation and integration evolved during the Cold War.

The lessons that France and the U.K. drew from the Suez Crisis in 1956, along with the return of Charles de Gaulle to power in France in 1958, molded their foreign and security policies for decades. While the U.K. concluded that it could not go against the wishes of the U.S., de Gaulle and his followers concluded that France should aim at self-sufficiency and independence-sometimes even balancing between both sides in the Cold War conflict - which was consistent with the value de Gaulle placed on sovereignty and on la grandeur de la France. Tensions between France and the U.S., but also between France the EEC, due to its supranational nature and path, were high until de Gaulle resigned in 1969. ${ }^{22}$ These tensions were made manifest in France's creation of its own nuclear deterrent force in 1959; the Fouchet Plan of 1961-62, designed to create an intergovernmental regime able to overrule the supranational actions of the EEC; ${ }^{23}$ the Chaise Vide Crisis; ${ }^{24}$ and the decision to abandon the military structure of NATO (but stay in the Atlantic Alliance). ${ }^{25}$

21 The Western Union had five signatories: Belgium, France, Luxembourg, Netherlands, and the U.K. Actually, the Western Union extended the provisions of the Treaty of Dunkirk (1947), established between France and the U.K., to the BENELUX countries.

As some authors suggest, both had strong interests that came into conflict: "Aucun pays au monde, en dehors de la France et des États-Unis, ne proclame qu'il a un message à apporter au reste de la planète.” Axel Poniatowski, Pourquoi les Français et les Américains ne se Comprennent Plus (Paris: Perrin, 2004), 132. Or: "for two centuries France, as a messianic nation which wants to be the teacher of the human race, exists in a competitive relationship with the United States, and tries, like the United States, to establish a model of civilization valid for the entire planet.” Blunden, “France,” 22.

The Fouchet Plan collapsed due to a lack of support of the other member-states of the Communities. In the realist tradition, de Gaulle then attempted a back door proposal with Germany that it alone should assume the direction of the Communities through the Elysée Treaty (1963), but German insistence on maintaining special transatlantic ties frustrated him and led him to ignore the treaty afterwards. 
Despite these troubles, the customs union between the six member states of the EEC became a reality eighteen months earlier than agreed, and the Common Agricultural Policy (CAP), which is France's favorite community policy, was already generating the surpluses that made so often the news.

Just after de Gaulle resigned, the Hague Summit in 1969 decided to admit the U.K. to the Communities and pressed ahead with the integration process. ${ }^{26}$ After the Davignon Report in $1970,{ }^{27}$ the European Political Cooperation (EPC) format was adopted as an intergovernmental forum for the six member states to interact, outside of the Communities, in high politics (foreign and security policy), where a need for coordination between European states in world affairs was felt. ${ }^{28}$ The Arab-Israeli conflict or the strategy for confronting the Soviet threat were often dealt with differently by different European states, which created problems with each other that could have been avoided by consultations and consensus before policies and positions were adopted in each capital. The results were mixed at first: the 1973 Arab oil embargo still revealed wide differences within Europe, but at the signature of the Final Act of the Conference on Security and Cooperation in Europe, in Helsinki in 1975, Europe offered a show of unity. ${ }^{29}$ But this was a vague document, and thus was easy to agree with.

During the 1970s, the EC—-now increased to nine member states—was suffering a relative economic decline in relation to Japan and the U.S. ("Eurosclerosis"30), with budgetary problems, CAP surpluses, and the Common Market a mirage. ${ }^{31}$ Europe was

24 For six months France abandoned the work of the Council of Ministers of the Communities to protest decisions about the CAP with which it disagreed. This conflict was dealt with in the Compromise of Luxembourg of 29 January 1966. See Zorgbibe, Histoire de la Construction Européenne, 61-62; Trevor Hartley, The Foundations of European Community Law, $4^{\text {th }}$ edition (Oxford: Oxford University Press, 1998), 20; Michael Burgess, Federalism and European Union: The Building of Europe, 1950-2000 (London: Routledge, 2000), 83-85. As Burgess writes of the compromise, "its appellation was a misnomer since there was only an agreement to disagree...” (84).

25 France abandoned the military commands and defense planning structures, and demanded that the NATO headquarters leave Paris; so they were moved to Brussels, where they remain.

26 The single currency and the Communities Own Resources are the other most important decisions of the Hague Summit. See Burgess, Federalism and European Union, 86-89; Dick Leonard, Guide to the European Union, $4^{\text {th }}$ edition (London: The Economist, 1994), 11-12; Urwin, The Community of Europe, 146-57; and Zorgbibe, Histoire de la Construction Européenne, 91-97.

27 Named after the Belgian Étienne Davignon who retained the main ideas of the failed Fouchet Plan.

28 Zorgbibe, Histoire de la Construction Européenne, 165-66.

29 "[S]etting a tone and standard for the future, the Helsinki Final Act ... was signed by Aldo Moro 'for Italy, and in the name of the European Community."' Urwin, The Community of Europe, 149.

30 Robert Jones, The Politics and Economics of the European Union (Cheltenham, U.K.: Edward Elgar Publishing Ltd., 1996), 22-23.

31 And the ECJ confirmed it in the Cassis de Dijon Sentence of 20 February 1979, on case C$120 / 78$. 
an economic power, but it was politically fragmented in its approach to world affairs. To solve this crisis, European leaders agreed in 1985 to a revision of the Treaty of Rome, the Single Europe Act (SEA), ${ }^{32}$ which defined an ambitious program to reduce internal barriers to trade in order to create a truly single market by 1992 and to institutionalize the EPC. The EPC would further integration and offer economic gains from increased competition and from the scale of a larger market. To have effective and faster implementation of the directives that would remove the old barriers and introduce new EEC-wide rules, it was also agreed to decide more matters by qualified-majority voting (QMV), thus increasing substantially the supranational power of the EEC. $^{33}$

Because of this, the SEA was a major step in the integration process, and thus it was inevitable that it brought pressure to end the Article 223 provisions exempting the defense sector due to the distortion it imposed on markets. Concerns about autonomy on the traditional pillar of sovereignty and negative economic implications for domestic industries were more important to member states than the potential savings, whose estimates were controversial even then, so Article 223 remained in place.

The collapse of communism and the move toward German reunification forced a new revision of the treaties, but on a more ambitious scale. The Maastricht Treaty of 1992, also known as the Treaty of the European Union (TEU), ${ }^{34}$ aimed at advancing political union by creating a single framework to deal with high politics and low politics - namely, the EU, with a three-pillar structure (figure 1): the first pillar, the Communities, is supranational, while the other two are intergovernmental (the second for the CFSP, and the third for justice and home affairs). This model ensured that national governments still retained control over all levers of power on defense, except they could not finance operations from the EEC budget (Article J.11; now Article 28 of the TEU). Among many important changes brought about by the TEU, matters of security and defense were addressed for the first time institutionally by the European states outside of the framework of military alliances, like NATO, and with ambitious integration goals, as stated in Article J.4: “The common foreign and security policy shall include

32 Signed in Luxembourg on 28 February 1986, and entered into force on 1 July 1987, when the Communities already had twelve member states, including Portugal and Spain (since January 1987). See Urwin, The Community of Europe, 229-46; and Burgess, Federalism and European Union, ch. 5.

33 Many people consider the SEA the single biggest increase in supranationality-and therefore, integration - that the EEC has experienced to date. For some, such as Margaret Thatcher, the then Prime Minister of Britain, it was a big mistake: "I believe that in negotiating the Single European Act we in Britain made two understandable but undeniable mistakes. The first was to assume that the increased powers given to the Commission would cease to be used to any great extent once the Single Market program had been completed. ... The second error ... was then and later to take at face value the assurances we were given.” Margaret Thatcher, Statecraft: Strategies for a Changing World (New York: HarperCollins Publishers, 2002), 374-75.

34 It was signed on 7 February 1992, and entered into force on 1 November 1993. 


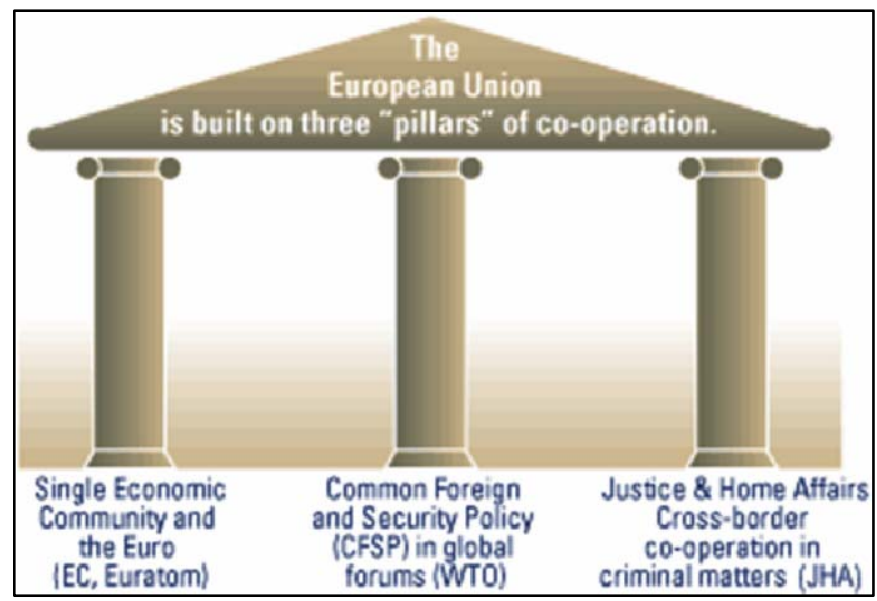

Figure 1: The EU Pillar Structure Introduced by the Maastricht Treaty.

all questions related to the security of the Union, including the eventual framing of a common defense policy, which might in time lead to a common defense."

The exclusion in Article 223 of the Rome Treaty was kept in place; its contents were superficially changed, and it became Article 296. Again, concerns about autonomy on the traditional pillar of sovereignty were more important to the member states than the costs of fragmentation, particularly for the U.K., which has one of the strongest defense industries and armed forces in Europe. By mutual agreement, the EU would use WEU assets to implement decisions on defense (per Article J.4(2)), but the EU would assume the defense-related functions of the WEU after 2001.

In 1987, France and Germany agreed to create a common brigade to execute NATO or WEU missions. But it was only at a German-French summit meeting in La Rochelle in 1992 that the decision was made to create the Eurocorps (Spain and Belgium joined later). ${ }^{35}$ The unit has been operational since 1995 . In a similar way, in 1995 France, Italy, Portugal, and Spain created two forces by international treaty-the Eurofor (land) and Euromarfor (maritime) —which are also tasked with carrying out NATO or WEU missions. The command of these forces rotates among military officers of the participating member states. Although all member states accept the principle of peaceful resolution of conflicts, it is nonetheless remarkable that these nations have been willing to accept the fact that their military forces would serve under foreign command (although that had always been the case in NATO, and was the main factor that led France to abandon its integrated military structure in 1966). The slow pace of

35 The full text of the La Rochelle Declaration is available at http://www.ena.lu/statement establishment_franco-german_european_army_corps_rochelle_22_1992-020004307.html. 
development in the area of defense cooperation thus defies understanding, and can apparently only be attributed to reasons of low politics.

More meaningful European cooperation in defense started at Maastricht, and continued during the 1990s, mostly under the rubric of the WEU (part of the intergovernmental pillar). It was the WEU that defined the so-called Petersberg Tasks. ${ }^{36}$ The crises in the former Yugoslavia during the 1990s (and the failure of the Europeans to solve them without U.S. intervention) cooled off the level of European optimism about the prospects of defense cooperation. The Western European Armaments Group and the Western European Armaments Organization, which were expected to be the nucleus of a European arms agency, never met the expectations placed on them when they were created. ${ }^{37}$ Even so, cooperation achieved some results, as the EUREKA program and the European Space Agency (ESA) show.

The Amsterdam Treaty, signed in 1997, was the first revision of the TEU. ${ }^{38}$ Among the changes it brought, the approach to defense matters became more nuanced. Article J.4 became Article J.7, and was rewritten as follows: "The common foreign and security policy shall include all questions relating to the security of the Union, including the progressive framing of a common defense policy, in accordance with the second subparagraph, which might lead to a common defense, should the European Council so decide."

The new Article J.7 also includes a vague reference to the creation of an armaments agency: "The progressive framing of a common defense policy will be supported, as Member States consider appropriate, by cooperation between them in the field of armaments.”

The device of constructive abstention was added to the CFSP pillar (in Article J.13), by which a member state that did not want to be part of a given decision could abstain, and thus avoid subsequent involvement, thus allowing the others to proceed without consensus or unanimity, as is the norm with intergovernmental methods. CFSP, the Schengen Agreements, and the Monetary Union are examples of variable geometry in the EU, a concept first formally proposed in a 1975 report by Belgian Prime Minis-

36 So named after the castle near Bonn where the WEU summit specifying the tasks took place. The tasks are: humanitarian and evacuation operations; peacekeeping; crisis management; and peace enforcement (Article 17-2). The full text of the Petersberg Declaration is available at www.assembly-weu.org/en/documents/sessions_ordinaires/key/declaration_petersberg. php.

37 Todd Sandler and Keith Hartley, The Political Economy of NATO (Cambridge: Cambridge University Press, 1999), 21-17; and John Lovering, "Rebuilding the European Defence Industry in a Competitive World: Intergovernmentalism and the Leading Role Played by Companies," in Restructuring the Global Military Sector, Vol II: The End of Military Fordism, ed. Mary Kaldor, Ulrich Albricht, and Genevieve Schméder (London: Pinter, 1998), 225-27. It was signed on 2 October 1997, and entered into force on 1 May 1999. 
ter Leo Tindemans. ${ }^{39}$ Amsterdam also created the post of High Representative (HR) for CFSP, to be exercised by the Secretary-General of the Council, as a sort of EU minister for foreign affairs. This was a small but very important step (in institutional terms) toward political union.

Few events had the relevance of the St. Malo summit meeting in 1998 between British Prime Minister Tony Blair and Jacques Chirac, the President of France. This meeting marked the turning point at which the U.K. agreed to be part of a European non-NATO common approach to defense. ${ }^{40}$ Six months later, the Cologne European Council created the European Security and Defense Policy (ESDP) within the framework of the CFSP, ${ }^{41}$ which would be focused on security, and had the potential to be significantly more effective than CFSP, despite its high politics nature. From then on, the EU took on the missions that it had planned to delegate to the WEU. To give substance to the ESDP, the Helsinki European Council in December 1999 defined the Helsinki Forces Headline Goal, to be realized by 2003: the ability to put in place within sixty days an expeditionary force of up to 50-60,6000 military personnel to be deployed for at least a year that is able to execute of the full range of Petersberg Tasks. $^{42}$

Two wars also played a crucial role in the creation of the ESDP: those in Bosnia (1992-95) and Kosovo (1999). If the technological and military gap between the United States and the Europeans was visible since at least the first Gulf War in 1991, ${ }^{43}$ it became strikingly obvious to all Europeans in Kosovo. The U.S., pushed into acting

39 Leo Tindemans, L’Union Européenne. Rapport de M.Leo Tindemans au Conseil Européen, Commission des Communautés Européennes, Bulletin des Communautés Européennes, Supplément $1 / 1976$. The full text of the report is available via www.ena.lu/the_tindemans_ report-020100267.html.

40 The text of the joint declaration from the summit is available at www.atlanticcommunity.org/ Saint-Malo\%20Declaration\%20Text.html.

41 Since Maastricht, Denmark has secured an option to opt out of defense matters in the TEU.

42 It should be noted, as a point of reference, that it took the U.K. in 2003 seventy days to put in place a military force of 45,000 men in Kuwait; "European Defence: Ready or Not," The Economist (24 May 2003): 29.

43 The gap is especially noticeable in the areas of expeditionary capacity, satellite communications, and intelligent weapons. For a deeper analysis of the gap by subsectors see Assembly of the WEU, The Gap in Defence Research and Technology Between Europe and the US (Paris: WEU, Document A/1718, 6 December 2000); Fondation pour la Recherche Stratégique (FRS), Analyse de la Notion de 'Gap' - Le 'Gap' Transatlantic (Paris: FRS Research and Documents, No. 27, May 2002); Katia Vlachos-Dengler, From National Champions to European Heavyweights: The Development of European Defense Industrial Capabilities Across Market Segments (Santa Monica, CA: RAND Corporation, DB-358-OSD, 2002); and Keith Hartley, “The Future of European Defence Policy,” Defence and Peace Economics 14:2 (January-March 2003): 107. The current discussion about the gap is the modern equivalent of the 1960s discussion about burden-sharing; see David Yost, "The U.S.-European Capabilities Gap and the Prospects for ESDP," in Defending Europe: The EU, NATO and The Quest for European Autonomy, ed. Jolyon Howorth and John T.S. Keeler (New York: Palgrave-MacMillan, 2003), 86-93. 
as "Europe's pacifier," ${ }^{44}$ had to use force on European soil to solve a European problem that the Europeans could not agree among themselves how to solve, and which they lacked the means to address. As Peter van Ham wrote, “'Kosovo' made it painfully clear that Europe depends upon the American military capabilities. However, it also underlined the reality that US leadership in Europe is tenuous and that most Americans are unwilling to risk their lives in messy European conflicts in which their national interests are hardly at stake." ${ }^{45}$ Philip Gordon echoed the impact of U.S. intervention in Kosovo: "Europeans now seem to understand better than before how great the capabilities gap is. ... Neither their publics nor their leaders seem prepared to make the financial sacrifices necessary to produce such capabilities any time soon."46

The second revision of the TEU came with the Nice Treaty. ${ }^{47}$ It kept the changes introduced in the previous revision and institutionalized, under the Council of Ministers, the military resources needed for the missions that the EU committed itself to in Maastricht and Amsterdam but, in the end, could not delegate to the WEU. The Council includes the Political and Security Committee (PSC), which has power to negotiate treaties, ${ }^{48}$ and can give guidelines to the Military Committee (EUMC), ${ }^{49}$ whose chairman participates in the PSC meetings. There is Military Staff (EUMS) under the authority of the EUMC, whose role is to implement the decisions and guidance of the EUMC. $^{50}$ This is the current EU arrangement for carrying out its military missions: a small planning cell without military forces, which is made up of primarily the same member states that allocate forces for NATO missions, which are deployed under national, not EU, command. This model seems to provide some duplication of NATO structures (if not an outright alternative), ${ }^{51}$ although NATO has a full planning capability, more assets, and more experience than the EU.

44 To use Josef Joffe’s expression; see Josef Joffe, “Europe’s American Pacifier,” Foreign Policy 54 (Spring 1984): 64-82.

45 Peter van Ham, Europe's New Defense Ambitions: Implications for NATO, the U.S. and Russia, The Marshall Center Papers No. 1 (Garmisch-Partenkirchen: George C. Marshall European Center for Security Studies, 30 April 2000), 8.

47 It was signed in 26 February 2001, and entered into force on 1 February 2003. Created by Council Decision 2001/78/CFSP of 22 January 2001, but it received full legal basis in 2003 in Article 25 of the TEU, entering into force after the Nice revision. Created by Council Decision 2001/79/CFSP of 22 January 2001.

${ }^{50}$ Created by Council Decision 2001/80/CFSP of 22 January 2001.

51 Wished for by the Euro-Gaullists. In one of the numerous examples of Euro-Gaullist assertiveness, specifically about the 2003 invasion of Iraq, Belgium, France, and Germany floated the idea of deepening the integration process among themselves, including the creation of a defense planning organization independent of NATO, and proposed the city of Tervuren (Belgium) as its central location. Then the idea was quietly dropped. See "Europe in the World: Facing Responsibility," The Economist (23 November 2002): 21-23; "Will a Quartet of Euro-enthusiasts Undermine NATO?” The Economist (03 May 2003): 27-28; Steven Everts and Charles Grant, Mission Impossible? Managing the Growing Divide Between Europe and the US (London: Centre for European Reform, 23 December 2002). 
Even during the Iraq crisis in 2003, France and the U.K. promoted approaches that relied on defense cooperation and ESDP action. At a summit meeting in Le Touquet in 2003, Chirac and Blair agreed on the general terms of the first ESDP mission, called Concordia, and carried out in the FYR Macedonia. ${ }^{52}$ They also reached agreement on the creation of an intergovernmental defense agency to implement the capability development required by ESDP, and on the creation of rapid (fifteen days) military reaction forces, made up of about 1500 ground troops from either one member state or from several, in cases where interoperability is not a problem. These forces would later become known as "battle groups," and met with robust participation by most EU member states; the groups achieved full operational capability in $2007 . .^{53}$

Significantly, the EU adopted its own security strategy for the first time in 2003, asserting itself as a security actor. ${ }^{54}$ Since then, the EU, via the ESDP, has assumed the responsibility for some international military missions, as shown in Table 1, albeit using the means of NATO or of certain member states (the EU has taken on a combined total of fifteen military and non-military missions). However one assesses these facts, it is remarkable how far Europe has come since 1951, when the integration process began with a cooperation agreement limited to the economic sectors of coal and steel.

Table 1: EU Military Missions under the ESDP. ${ }^{55}$

\begin{tabular}{llll}
\hline Mission & Country & Beginning/End & Framework \\
\hline CONCORDIA & FYR Macedonia & $\begin{array}{l}\text { 31 March / 15 } \\
\text { December 2003 }\end{array}$ & NATO/Berlin+ \\
\hline ARTEMIS & D.R. Congo & $\begin{array}{l}\text { 12 June / 1 } \\
\text { September 2003 }\end{array}$ & France \\
\hline EUFOR-Althea & $\begin{array}{l}\text { Bosnia and } \\
\text { Herzegovina }\end{array}$ & $\begin{array}{l}\text { 2 December 2004 / } \\
\text { ongoing }\end{array}$ & NATO/Berlin+ \\
\hline EUFOR-Chad/RCA & Chad / RCA & $\begin{array}{l}\text { March 2008 / } \\
\text { ongoing }\end{array}$ & France \\
\hline
\end{tabular}

${ }^{52}$ Full text of the Le Touquet Declaration is available at www.ambafrance-uk.org/FrancoBritish-summit-Declaration,4970.html?var_recherche=touquet.

53 The designation battle groups appeared for the first time in the declaration of the FrancoBritish Summit of London of 24 November 2003. The troops allocated to the battle groups are the same offered to the NATO Response Force. See Steven Everts, L. Freedman, C. Grant, F. Heisbourg, D. Keohane, and M. O’Hanlon, A European Way of War (London: Centre for European Reform, May 2004); Gustav Lindstrom, Enter the EU Battlegroups, Chaillot Paper No. 97 (Paris: WEU-ISS, February 2007).

54 European Council, A Secure Europe in a Better World - The European Security Strategy (Brussels, 12 December 2003).

55 All EU missions taken on under the ESDP are listed at www.consilium.eu.int/cms3_fo/ showPage. asp?id=268\&lang=pt. 
Without planning capabilities and assets of its own, the EU made use of assets on loan from NATO for EU-led crisis management operations (CMO) under the "BerlinPlus" framework agreement. ${ }^{56}$ In addition to capabilities or assets, the EU may request a NATO commanding officer for an EU-led military operation, and the Berlin-Plus arrangement establishes the Deputy Supreme Allied Commander Europe as the first candidate for the job.

Both organizations are pleased with this level of cooperation and the transparency of the relationship. It should be noted that it also allows the United States and Turkey, as NATO members, to know in some detail about-and, to a certain degree, to interfere in-EU-led operations. But this is only as it should be, since their assets may also be involved in these missions and, since they are member states of NATO, they may thus be dragged into a crisis situation or war.

The financing of EU operations under the ESDP is subject to the ATHENA mechanism, in the CFSP budget of the Council. ${ }^{57}$ According to the TEU, the Communities budget can support administrative expenses, but (in general) not operational ones. ${ }^{58}$

The latest political and institutional development of the European integration process is the Treaty of Lisbon. ${ }^{59}$ After failing to get the constitutional treaty ratified, due to its rejection in referenda in France and the Netherlands in 2004, the EU took stock and adapted the text produced by the Convention on the Future of Europe (2002-03) to a revision of the treaties. It was signed in Lisbon on 13 December 2007, and it is expected to be ratified during 2008 and be in force in 2009. In relation to defense broadly construed, the following points should be noted:

- $\quad$ The EU is to succeed the European Community and the pillar structure is to be abandoned, but the community and intergovernmental decision methods will remain largely as before

- $\quad$ The HR for CFSP becomes HR of the Union for Foreign Affairs and Security Policy, and will be Vice-President of the European Commission (ECom), and hence subject to consent by the European Parliament (joining two old pil-

56 Which consists essentially of an exchange of letters between EU and NATO representatives; dated 17 March 2003.

57 Established in Council Decision 2004/197/CFSP of 23 February 2004, and altered by Council Decision 2004/925/EC of 22 December 2004 and Council Decision 2005/68/CFSP of 24 January 2005.

58

Annegret Bendiek and Hannah Whitney Steele, “The Financing of the EU's Common Foreign and Security Policy,” Stiftung Wissenschaft und Politik 16 (June 2006): 1-7.

59 After the creation of the European Defense Agency (2004), which is addressed elsewhere in this article. The Treaty of Lisbon will be, if and when it is ratified by all twenty-seven EU member states, the third revision of the TEU, and will reform the European Communities. It will be designated the Treaty on the Functioning of the European Union. 
lars - the intergovernmental pillar of the CSFP, and the Community pillar of the ECom); he will also have a European foreign service ${ }^{60}$

- Creates the post of President of the European Council, elected by its members, for a term of two-and-a-half years, mainly for external representation of the EU

- Creates a solidarity clause, recognizing that NATO is the primary alliance for collective defense

- The defense exception was maintained, but its contents were moved from Article 296 to Article 346

- No significant change was made to the dispositions relative to the CFSP (Article 17 of TEU after Nice), except that the European Defense Agency (EDA) now has treaty-dignity.

Enhanced Cooperation status was extended to the CFSP in Nice, as a variable geometry device within the EU, but the minimum number of states to initiate a mission was raised to nine. ${ }^{61}$ This was intended to provide a possible alternative to states that decide to deepen their cooperation within the EU framework, instead of seeking such cooperation under a new international treaty, like Schengen. However, the procedures involved in an Enhanced Cooperation arrangement are complicated, and the advantages it holds over an international treaty are not obvious.

\section{European Defense Economics}

This section reviews briefly the main developments related to the politico-economic side of the defense sector. Integration in this sector requires many steps primarily at the political level, so that only after the regulatory framework is in place can markets function across borders. That is my main concern here, instead of the specific evolution of defense equipment, defense industries, or the market in general.

Defense Resources. By the 1960s, the success of the process of European integration and significant improvements in national economies and standards of living were clear, while the U.S. saw its external accounts deteriorate, in part because of the costs of maintaining its forces in Europe. This disparity led to the discussion of burdensharing within $\mathrm{NATO}^{62}$; the U.S. asked the Europeans to take on more of the costs of

60 This would seem to be a new European diplomatic corps, but it is still very vaguely characterized in Article 27 of the TEU.

${ }^{61}$ It is a mechanism created with Amsterdam, except for the second pillar, which had to wait until Nice (Article 27). The conditions for Enhanced Cooperation in the CFSP because of their rigidity became known as the "ten commandments."

62 Mostly by Charles Hitch and Roland McKean, The Economics of Defense in the Nuclear Age (Cambridge, MA: Harvard University Press, 1960), ch. 15; and Mancur Olson, The Logic of Collective Action: Public Good and the Theory of Groups (Cambridge, MA: Harvard University Press, 1965). For an academic anlysis in the field of economics, see Mancur Olson and Richard Zeckhauser, "An Economic Theory of Alliances," The Review of Economics and Statistics 48:3 (August 1966): 266-79. 
operating NATO or face a reduction of U.S. forces and protection against the USSR. ${ }^{63}$ As a result, the Eurogroup was created inside NATO to be the main forum for arms and burden-sharing cooperation. ${ }^{64}$ In 1970, the European member states implemented a coordinated increase of 3 percent of their arms expenditure for NATO through the Eurogroup, in the European Defense Improvement Program. ${ }^{65}$

Until then, and in most cases after that, arms were acquired by each NATO state on a purely national basis, creating duplication and interoperability problems. Despite the advantages of standardization, there was success in NATO only at the operationalmilitary level. Thomas Callaghan estimated in 1975 that market fragmentation in NATO costs Europe about 25 percent of its combined arms procurement budget, and 10 percent in the U.S., compared to a free trade system for defense products within NATO. This amounted to a total of about USD 10 billion, which was hardly small change. ${ }^{66}$

When implementing the SEM, there was pressure to eliminate Article 223 and the defense exclusion, but nothing changed. ${ }^{67}$ Concerns about autonomy on a critical pillar of sovereignty were more relevant to the member states than the costs of fragmentation, which were only then becoming clear:

NATO's defense budget resources are wasted.... The waste begins as duplication of effort in the development phase, continues as a loss of economy of scale in the production phase, and peaks as a waste of facilities, spares, overheads and (particularly) manpower in the logistic support phase. ... With different weapons and equipment, requiring different ammunition and spares, each Allied country must look to its own ... logistic support for re-supply. ... The weakest link in the entire Allied defense chain is thus this NATO vulnerability to sustained conventional at-

63 In that sense, there was strong pressure exerted in 1966 by U.S Senator Mike Mansfield; Gülnur Aybet, The Dynamics of European Security Cooperation, 1945-91 (London: Palgrave, 2001), 121.

It combined all European member states of NATO, represented by their National Armaments Directors (NAD). It is not related to the EU states that adopted the EURO as their common currency after 1999.

65 Carl Damm and Philip Goodhart, The Eurogroup (Brussels: North-Atlantic Assembly, 1972); Callaghan, U.S./European Economic Cooperation in Military and Civil Technology, 77-79; Sandler and Hartley, The Political Economy of NATO, 208-15; and Aybet, The Dynamics of European Security Cooperation, 122-26.

${ }^{66}$ Keith Hartley disputes Callaghan's assumptions, but agrees that the potential savings are significant. See Keith Hartley, NATO Arms Co-Operation (London: George Allen \& Unwin, 1983), 10-11.

67 Sandler and Hartley, The Political Economy of NATO, 159. 

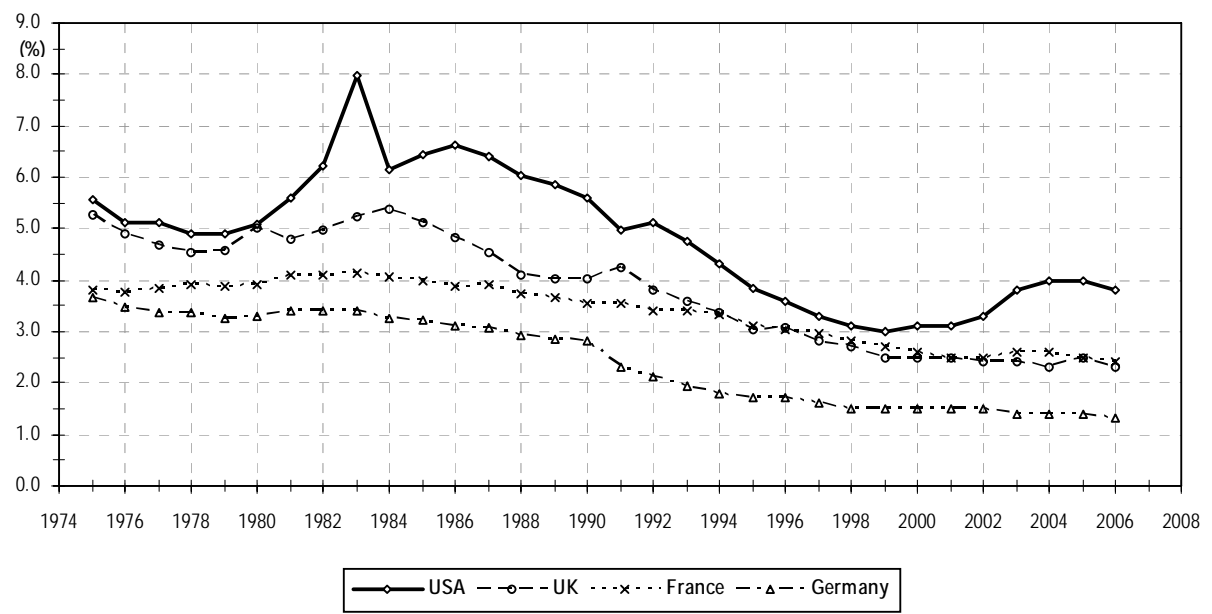

Figure 2: Defense Expenditures as a Fraction of the Respective GDP (Source: NATO).

tack. ... There is no lack of resources. What has been lacking is a coordinated effort pitting the technological and industrial resources of NATO. ${ }^{68}$

This situation generated a multidimensional gap between the U.S. and Europe, further aggravated by a consistent difference in the fraction of national resources allocated to defense, which has been much smaller in the EU for the last thirty years, as shown in Figure 2 (before 1975 it was nearly the same).

Hartley and Cox estimated the "costs of non-Europe" at about 10-20 percent of total EEC weapons acquisition costs. ${ }^{69}$ If the EU started a program of capability improvement in order to eliminate the gap with the U.S.—even if it had a single defense market for arms-it would still need to spend between USD 23-56 billion in order to achieve a comparable level of military capabilities. ${ }^{70}$

If a defense free trade area allowed annual savings of USD 10-15 billion, it would require two years (at best) to reduce the gap. In fact, such savings take time to materi-

68 Thomas A. Callaghan, Jr., U.S./European Economic Cooperation in Military and Civil Technology (Washington, D.C.: CSIS Press-Georgetown University, September 1975), 14 and 35-37. As Robert Grant wrote, "EU member states spend the equivalent of about $60 \%$ of the US defence budget, but the return in military capabilities is only the equivalent of $10 \%$." Robert Grant, The RMA - Europe Can Keep in Step (Paris: ISS-WEU, Occasional Paper No. 15, June 2000), 2-3.

Keith Hartley and Andrew Cox, The Costs of Non-Europe in Defense Procurement. Main Report (Brussels: European Commission-DGIII, May 1988).

70 Data from a study from the RAND Corporation for four scenarios; See Charles Wolf, Jr. and Benjamin Zycher, European Military Prospects, Economic Constraints, and the Rapid Reaction Force (Santa Monica, CA: RAND Corporation, MR-1416-OSD/SRF, 2001). 
alize, and the U.S. would continue to pull away from Europe, while arms unit costs would still continue to grow rapidly. In addition, arms take time to fabricate, and the armed forces take time to integrate them and make them fully operational. In short, one could estimate roughly a period of no less than five years to close the gap; this is considering only the technical timetable, with all political conditions presumed to be favorable.

So, all studies show that the product obtained by combining all the European programs based on autonomous national budgets is not the same as the product obtained with one single defense budget equal to that total. But fragmentation still persists, as Table 2 shows.

Table 2: Fragmentation in Europe ${ }^{71}$ (Source: EU, 1995).

\begin{tabular}{lcc}
\hline System & Europe & U.S. \\
\hline Land Systems & 4 & 1 \\
\hline Main Battle Tank & 16 & 3 \\
\hline Armored Infantry Vehicle & 3 & 1 \\
\hline 155mm Howitzer & & \\
\hline Air Systems & 7 & 5 \\
\hline Attack Fighter & 6 & 1 \\
\hline Ground Attack Trainer & 7 & 5 \\
\hline Attack Helicopter & 9 & 3 \\
\hline Anti-ship Missile & 8 & 4 \\
\hline Air-air Missile & & \\
\hline Naval Systems & 11 & 1 \\
\hline Frigate & 9 & 2 \\
\hline Anti-submarine Torpedo & 7 & 0 \\
\hline Diesel Submarine & 2 & 1 \\
\hline Nuclear Powered Submarine & 89 & 27 \\
\hline TOTAL & & \\
\hline
\end{tabular}

${ }^{71}$ Jean-Pierre Darnis, G. Gasparini, C. Grams, D. Kehoane, F. Liberti, J.P. Maulny, and M.B. Stumbaum, Lessons Learned from European Defence Equipment Programmes, Occasional Paper No. 69 (Paris: WEU-ISS, October 2007), 18. See also Pierre De Vestel, Defence Markets and Industries in Europe: Time for Political Decisions?, Chaillot Paper No. 21 (Paris: WEU-ISS, November 1995); and UNISYS, Intra-Community Transfers of Defence Products: Final Report (Brussels: European Commission, February 2005). 
The gap still widens due to the continuous growth in the unit cost of weapons, for one or more of the following reasons ${ }^{72}$ :

- The increased costs of research and development (R\&D) for increasingly sophisticated requirements and technological solutions

- The increased production costs of more sophisticated systems

- Despite some export successes, smaller production runs in Europe, which cannot dilute large overheads and exploit economies of learning.

This point suggests that small states should be the champions of free trade; that is the only way they can sell in large enough markets, and have sufficiently long production runs (even if only in niche areas) to dilute overheads and economically justify a product. However, past experience shows that small states tend to focus on protecting inefficient domestic industries, through offsets and juste retour. ${ }^{73}$

In fact, there is a free trade area in arms between two NATO members, and a successful one too: it is based on the 1941 Hyde Park Agreement between the United States and Canada. ${ }^{74}$ Proposals for all NATO states to reject protectionism and create a transatlantic defense market (a free trade area in arms) would be consistent with the principles of cooperation and peaceful conflict resolution of the NATO alliance. ${ }^{75}$ Such appeals have been aired since 1975, but without success. ${ }^{76}$

The most important point, however, is the increase in efficiency that could be internalized forever. Not only that: the fears of lagging behind, and of an increasing tech-

72 Philip Pugh, “The Procurement Nexus,” Defence Economics 4 (1993): 179-94; David Kirkpatrick, "The Rising Unit Cost of Defence Equipment-The Reasons and The Results," Defence and Peace Economics 6 (1995): 263-88; and David Kirkpatrick, "Trends in the Costs of Weapon Systems and the Consequences,” Defence and Peace Economics 15:3 (June 2004): 259-73.

73 Offsets are forms of compensation, offered through coproduction, technology transfers, or barter, that some governments demand from foreign arms producers when importing arms; see Callaghan, U.S./European Economic Cooperation in Military and Civil Technology, 55. Juste retour, also called "fair shares" or "fair return," is a method of balancing the transactions within a given project. As Thomas Callaghan writes, "Because the make-buy transaction (or project) must be financed by the cooperating countries' defense budgets, the tendency has been to balance the financial, industrial, technological and economic accounts within the project.” Callaghan, U.S./European Economic Cooperation in Military and Civil Technology, 53, 40.

74 Full text of the Hyde Park Agreement is available at http://www.questia.com/PM.qst?a=o\& $\mathrm{d}=14931400$.

75 "National autarky makes neither military nor economic sense within an alliance. Having taken the step of relying on our allies for mutual front line defense against the USSR, it is inconsistent to argue that we can not rely on them to supply weapons....” Deborah Logsdon, European Community Defense Industries: Threat to U.S. Competitiveness? (Washington, D.C.: The Industrial College of the Armed Forces, National Defense University, 1993), 32.

76 Callaghan, U.S./European Economic Cooperation in Military and Civil Technology, 57 and 106. 
nological gap between the EU and the U.S., should fade and eventually vanish, along with many vestiges of political rivalry.

The end of the Cold War brought a reduction of defense expenditure and forcesthe so-called peace dividend-estimated at USD 106 billion per year. ${ }^{77}$ The downside of this dividend, however, was factory closures, job losses, and regional recessions. ${ }^{78}$ To help governments deal with the social consequences and to mitigate the losses, the ECom created the PERIFRA ${ }^{79}$ and KONVER ${ }^{80}$ programs, with funding of about ECU 3 billion from 1991-99, to support training of jobless workers and conversion of defense industries.

This shows that a matter that was apparently purely confined to the defense arena had a wider social impact, that a gain (the peace dividend) can also have a downside, and how the pillars of the EU have to work together, just as in domestic policy. It also shows that there are ways to compensate for the negative implications of defense restructuring.

Cooperation in Arms Procurement. It was noted that in 1945 there was autarky and no cooperation among the Europeans, or between European states and the U.S. That changed definitively for the broader economy with the Marshall Plan in 1948, ${ }^{81}$ and for many European armed forces with the Mutual Defense Assistance Program. ${ }^{82}$

77 "Survey - Defence and the Democracies," The Economist (1 September 1990):16; and Hartley, "The Future of European Defence Policy,” 108.

${ }^{78}$ Germany suffered the biggest reductions (a total of 79 percent), mostly in the East (50 percent), followed by the U.K. (8 percent), Italy (4.5 percent), and France (4 percent). Bonn International Center for Conversion (BICC), Konver II-Fostering of Conversion by the European Union, Report 9 (Bonn: BICC, March 1997), 11. For the U.K., see Paul Bishop and Rose Gripaios, "The Regional Impact of Cuts in U.K. Defense Spending,” Defense Analysis 11:2 (1995): 175-87.

79 PERIFRA I (1991) had funding of ECU 40 million, of which 21 million was for conversions; PERIFRA II (1992) had funding of ECU 50 million, of which 31.4 million was for conversions; BICC, Konver II-Fostering of Conversion by the European Union, 19. KONVER I (1993) had funding of ECU 130 million; KONVER II (1994-99) had funding of ECU 500 million (about 0.4 percent of the Community Budget in each of those years) until 1997, but the funding level could increase to ECU 744 million in 1999.

81 "Through these and related initiatives American Marshall planners hoped to create an integrated European market - one that could absorb German power, boost productivity, raise living standards, lower prices, and thus set the stage for security and recovery on the Continent and for a fully multilateral system of world trade.” Michael Hogan, "American Marshall Planners and the Search for a European Neocapitalism," American Historical Review 90:1 (February 1985): 45.

82 "The new agreement affirmed in the military sphere what the Marshall Plan had pointed out in the economic sector - the necessity of American participation in all phases of the European quest for survival.” Hans A. Schmitt, The Path to European Union, 37. 
Cooperation started loosely and with small steps in the 1950s (the early stages of NATO), with particular successes in the development and production of aircraft. ${ }^{83}$ Forty programs of arms cooperation were started and completed between 1958 and 1998; France was the most active partner, followed by Germany, the U.K., and Italy. But the story of arms cooperation is irregular, and was marred by many failures. ${ }^{84}$

Having realized the limits of autarky, and concluding that European defense could not develop outside of NATO, France returned to the fold in 1995. A few days later, it agreed with Germany on a new set of principles on defense cooperation, to replace the current protectionist logic based on juste retour. After some small WEU member states refused to abandon the juste retour model, ${ }^{85}$ France, Germany, Italy, and the U.K. created (in the 1996 Treaty of Farnborough), the Organisation Conjointe de Coopération en matière d'ARmement (OCCAR), an international organization to manage contracts of collaborative arms acquisition or services provision. Given specifications produced elsewhere ${ }^{86}$ - for example, under contract or cooperatively-OCCAR manages contracts for delegations of participating states, and administers only one contract per common weapon system (as opposed to one specific weapon and contract per state), with obvious gains in scale and learning economies. OCCAR became operational in 2001, with Belgium and Spain joining later. The programs it currently manages are listed in Table 3.

Given the difficulties of dealing with classified matters and equipment, France, Germany, and the U.K. agreed in 1997 in principle to further the restructuring of their defense industries - mostly the electronics and aerospace subsectors - in order to make them more competitive with those of the United States. ${ }^{87}$ In 1998, the original OCCAR-four plus Spain and Sweden signed a letter of intent to simplify the restructuring (mergers, acquisitions, and closures). ${ }^{88}$ This was followed by a treaty completed

${ }^{83}$ The Transall C-160 is perhaps the best example; Reiner Pommerin, "Le Transall C 160. L'Histoire d'une 'Bête de Somme'," in Historie de la Coopération Européenne dans L'Armement, ed. Jean-Paul Hébert (Paris: CNRS Éditions, 2004), 45-53.

Patrick Facon, "Le Projet de Programme Commun Européen Aéronautique du Général Léchères, 1950-1953," in Historie de la Coopération Européenne dans L'Armement, ed. Jean-Paul Hébert, 17-25; and Jean-Paul Hébert, "D’Une Production Commune à Une Production Unique? La coopération Européenne en Matière de Production d'Armement Comme Moyen de Renforcement de l'Autonomie Stratégique Européenne," in Historie de la Coopération Européenne dans L'Armement, ed. Hébert, 200-17.

85 In particular, Greece and Belgium; Jocelyn Mawdsley, The European Union and Defense Industrial Policy, Paper 31 (Bonn: Bonn International Center for Conversion, 2003), 18.

${ }^{86}$ Axelle Masson, "Le Cadre Institutionnel de la Coopération en Matière d'Armement en Europe," in Historie de la Coopération Européenne dans L'Armement, ed. Jean-Paul Hébert, 194-95.

${ }^{88}$ Letter of Intent between Six Defence Ministers on Measures to Facilitate the Restructuring of the European Defence Industry, 6 July 1998. See Burkhard Schmitt, From Cooperation to Integration: Defence and Aerospace Industries in Europe, Chaillot Paper No. 40 (Paris: WEU-ISS, July 2000), 17. 
Table 3: OCCAR Current Programs (Source: OCCAR, 2005).

\begin{tabular}{lll}
\hline Program & \multicolumn{1}{c}{ System } & \multicolumn{1}{c}{ Collaborative States } \\
\hline A 400 M & Tactical and strategic airlifter & $\begin{array}{l}\text { Belgium, France, Germany, } \\
\text { Spain, Turkey, U.K. }\end{array}$ \\
\hline BOXER & Multi-role armored vehicle & Germany, Netherlands \\
\hline COBRA & Counter-battery radar & France, Germany, U.K. \\
\hline FREMM & Frégate Européenne multi-missions & France, Italy \\
\hline FSAF & Family of surface-air anti-missile & France, Italy \\
& systems & \\
\hline PAAMS & Principal anti-air missile systems & France, Italy, U.K. \\
\hline ROLAND & In-service support & France, Germany \\
\hline TIGER & Helicopter & France, Germany, Spain \\
\hline
\end{tabular}

in 2000 between the same states called the Framework Agreement. ${ }^{89}$ Two of these three instruments are treaties showing the will of the participating states to cooperate, but at the intergovernmental level and outside of the EU, although for overall EU benefit. $^{90}$

All the developments outlined above-and certainly those coming after the 1960s, with the pressures of increasing unit costs of arms, globalization, and spillover from other sectors and policies (foreign and domestic) - convinced the bigger states to cooperate in depth, and limit their autarky in the defense sector. In fact, no defense sector can be considered truly national any more, perhaps not even in the United States, let alone in Europe. $^{91}$

At the same time, small states remain protectionist. There may be two reasons for this. The first is that small states feel they will not be allowed to share power after the

${ }^{89}$ Framework Agreement Between The French Republic, The Federal Republic of Germany, The Italian Republic, The Kingdom of Spain, The Kingdom of Sweden and The United Kingdom of Great Britain and Northern Ireland Concerning Measures to Facilitate the Restructuring and Operation of the European Defence Industry, Farnborough, 27 July 2000.

90 Masson, "Le Cadre Institutionnel de la Coopération en Matière d'Armement en Europe," 193-97.

91 Livre Blanc de la Défense (Paris: La Documentation Française, 1994), 116, 120. 
restructuring of industries, ${ }^{92}$ so they would lose what little they have with no adequate compensation to show domestically. The second reason is that any losses in economic activity and sovereignty mean proportionally more to small countries than to bigger ones. The troubles of the seven-year experiment of two-headed (French and German) management at EADS-Airbus lend support to this view. ${ }^{93}$

In 1996, the ECom presented its first official communication about defense, in which it proposed the creation of an European Defence Equipment Market (EDEM). ${ }^{94}$ The European Parliament supported it, but the Council did not, nor did the member states that were not then ready to accept the loss of some "national champions" through mergers and closures. So the ECom reviewed its stance and presented two new communications in 1997, one on the aerospace industry (the most advanced and integrated of European defense industries, and also the one that faces the highest level of direct competition with the U.S.), and the other about defense industries in general. ${ }^{95}$ Having unsuccessfully aimed at eliminating Article 223, the ECom was able to press for a more restrictive definition of the limits of the defense exception, with the help of the European Court of Justice. ${ }^{96}$

In 2003, the ECom saw an important breakthrough, as Regulation 150/2003 was published, suspending import duties on certain weapons and military equipment - in effect bringing the arms trade within the Competition Policy (the exclusive domain of the Community) and representing a step toward setting up the EDEM. Later the same year, the ECom produced its latest communication about defense economics, but it failed to get support from the Council and the member states. ${ }^{97}$

92 Companies are not too effective if they practice a democratic decision-making process that demands wide discussion and shared agendas, so they avoid collective executive bodies and collective decision-making processes featuring many stakeholders and their circumstantially varying interests. The option for only one chief executive tends to serve the interests of the bigger states, which are in a much better position to fill that post with one of their own, even if on a rotating basis. They may argue that the biggest clients are the biggest shareholders too, hence they should have a right to control operations. But this is a self-defeating argument, since a company is preferred for its managerial professionalism, and this is no exclusive preserve of large states.

93 Through a very complicated shareholder structure, the French state and the German private company Daimler (currently; at its creation in 2000 it was Daimler-Chrysler) control EADS with equal stakes. See B. Schmitt, From Cooperation to Integration, 40-45.

94 European Commission (ECom), The Challenges Facing the European Defence-Related Industry: A Contribution for Action at European Level, COM(96) 10 (24 January 1996). European Commission (ECom), The European Aerospace Industry Meeting the Global Challenge, COM(97) 466 (24 September 1997); and Implementing European Union Strategy on Defence-Related Industries, COM(97) 583 (12 November 1997).

96 For example, on their decision in Commission v. Spain, of 29 October 1998, on the case C114/97, and on the decision in Commission v. Belgium, of 9 March 2000, on the case C$355 / 98$. The matter of proportionality of an exception or derogation was dealt with, among others, in the decision in Commission v. Spain, of 16 September 1999, on the case C-414/97. European Commission (ECom), European Defence - Industrial and Market Issues. Towards an EU Defence Equipment Policy, COM(2003) 113 (11 March 2003). 
Export Controls. Another important domain of EU action is on export controls, which are put in place to avoid the proliferation of weapons of mass destruction (WMD), as well as the means for their delivery (missiles), mines, small arms, or dualuse goods. The EU and its member states are part of several international regimes or treaties that impose both political and legal obligations on this trade. The most important are the Chemical Weapons Convention (a binding treaty, evolved from a 1925 Protocol); the Nuclear Non-Proliferation Treaty (in force since 1970), and the associated to it Zangger Committee and Nuclear Suppliers Group (regimes dedicated to the control of exports that can be used to fabricate nuclear weapons); the Biological and Toxin Weapons Convention (a binding treaty, in force since 1975); the Australia Group (created in 1985); the Missile Technology Control Regime (created in 1987); and the Wassenaar Arrangement (a regime created in 1996 to replace the CoCom, which was dissolved in 1995).

In 1998, the Council of Ministers of the EU also agreed on a Code of Conduct on the Arms Trade, but the form chosen for the code, a Declaration, means the member states of the EU have still only their weak political will to encourage them to avoid the destructive competition between them on the export of arms.

Industrial Restructuring and the Defense Market. A last note is in order about the transformations that have taken place in the European defense industries. The restructuring started domestically and then, after the 1998 Letter of Intent, crossed borders, generally following an Anglo-Saxon capitalist model of the private firm. By then, the U.S. had finished its own process of defense transformation. ${ }^{98}$ The restructuring efforts undertaken by various countries and firms can be classified in four main groups ${ }^{99}$ :

- $\quad$ Abandoning the defense sector (e.g., Philips and Siemens)

98 This process started at what has become known as the "Last Supper," in which the Deputy Defense Secretary William Perry announced cuts in U.S. defense procurement to an audience of chief executive officers of big defense firms, forcing the industries to restructure. See Harvey Sapolsky and Eugene Gholz, "Restructuring the U.S. Defense Industry,” International Security 24:3 (Winter 1999): 5; and Gilles Le Blanc, "Dépenses Militaires, Restructuration de l'Industrie d'Armement et Privatisation de la Défense: Analyse Comparée FranceÉtats-Unis 1994-1999,” Arès 28:46, fasc. 3 (2000): 48.

Sandler and Hartley, The Political Economy of NATO; François Heisbourg, ed., European Defence: Making it Work, Chaillot Paper No. 42 (Paris: WEU-ISS, September 2001); Vlachos-Dengler, From National Champions to European Heavyweights; Jean-Paul Hébert, “L'Européanisation de l'Industrie d'Armement et l'Autonomie Stratégique de l'Europe,” Arès 19:48, fasc. 2 (January 2002): 45-59; Defence Analysis Institute (DAI), Prospects on the European Defence Industry (Athens: DAI, April 2003); and Hartley, "The Future of European Defence Policy.” 
- Conversion of publicly administered services into private firms, e.g., the Direction des Constructions Navales (DCN), ${ }^{100}$ or Groupement Industriel de l'Armement Terrestre (GIAT) ${ }^{101}$

- Privatization of state-owned companies, ${ }^{102}$ e.g., British Aerospace (BAe), the Swedish firm Celsius, the Italian firm Alenia Aerospazio, the Spanish company Construcciones Aeronauticas, SA, the Greek firm Hellenic Shipyards, and the French companies Aérospatiale and Thompson-CSF

- Mergers and acquisitions, e.g., the creation of BAe Systems ${ }^{103}$ after buying Ferranti and GEC-Marconi, and the creation of EADS after Daimler-Chrysler Aerospace AG bought the Spanish company CASA and then merged with the two French firms Aérospatiale and Matra; also the creation of Thales (2000) from Thomson-CSF and others, and MBDA (2001) from Matra Défense, Lagardère and BAe Dynamics. ${ }^{104}$

After this wave of restructuring, Europe had four large defense groups, mostly transnational in scope, and able to compete with the big American companies of this sector:

- $\quad$ The British firm BAe Systems, broadly present in all defense industries

- EADS, registered in the Netherlands and controlled by the French state and the German company Daimler, strongest in the aerospace subsector

- Thales, mostly French, dedicated to several defense industry subsectors, but strongest in the information systems subsector

- $\quad$ MBDA, a British-French-Italian venture dedicated to the missile subsector.

It is true that these firms are still viewed largely as "national champions," or even as "European champions," with a duty to accommodate the national policies and interests of their shareholders. This weakens them, because it subsumes their desired

${ }^{100}$ French Government decision of July 2001, made effective in 31-May-2003; Jean-Daniel Levi and Hughes Verdier, De L'Arsenal à L'Entreprise (Paris: Albin Michel, 2004).

${ }^{101}$ Frédérique Barnier, "Les Transformations des Relations entre l'État et les Producteurs d'Armement: le Cas de GIAT-Industries," in État et Firmes d'Armement en Europe, ed. Jean-Paul Hébert (Paris: CIRPES, Collection Cahier d’Études Stratégiques, No. 22, 1998), 107-16.

102 Richard Kaufman, ed., Privatization in North-Atlantic Cooperation Council Countries Colloquium 1994 (Brussels, 30 June - 1 July 1994); Alexander Kennaway, "Privatization of Defence Industries in the Framework of Privatization at Large,” in Privatization in NorthAtlantic Cooperation Council Countries, ed. Kaufman; Jean-Paul Hébert, ed., État et Firmes d'Armement en Europe (Paris: CIRPES, Collection Cahier d'Études Stratégiques, No. 22, 1998), and Elisabeth Sköns and Richard Weidacher, “Arms Production,” SIPRI Yearbook 2002 (Oxford: Oxford University Press, 2002), 341-46.

${ }^{103}$ Yves Bélanger and Jean-Paul Hébert, "BAe Systems au Coeur du Processus de Globalisation de l’Industrie de Défense,” Arès 19:47 (April 2001): 41-54.

${ }^{104}$ B. Schmitt, From Cooperation to Integration: Defence and Aerospace Industries in Europe. 
commercial working logic to circumstantial political interests, thus losing focus. On the other hand, this privileged national footing gives them monopoly power and invulnerability before governments, as they are too big or too strategic to fail or go bankrupt.

To limit their power, they should compete globally, but this has yet to be explored due to the European inclination for protectionism, known as la préférence Européenne or "Fortress Europe." It is argued to the contrary that full competition with the stronger American firms will lead the Europeans to rapid bankruptcy or huge losses (particularly since, as is correctly noted, the U.S. also practices protectionism). ${ }^{105}$ However, there are signs of change in U.S. policy: the choice of Northrop Grumman-EADS (Airbus) to build a refueling aircraft in a competitive procurement program is helping the competition argument against protectionism. ${ }^{106}$

It is not clear what will be the long-term economic result of this restructuring wave: economies of scale and less duplication were its main motivations, but if there is no competition in the market and companies feel invulnerable to failure, there may be little pressure on managers to focus on generating value for money and containing costs and waste. It is also the case that the enormous and increasing cost of modern weapon systems demands that the producers of arms, besides selling to their own governments, export them in order to recover indirect costs. This is even more the case for the Europeans, because they produce shorter production runs of each item. Even after the recent rounds of restructuring, they tend to be focused on their home markets or have only limited access to foreign markets. It is for this reason that a free transatlantic defense market would be good for NATO.

Such a market, allowing for defense restructuring to operate across the Atlantic Ocean (as envisaged for the EDEM) will probably also bring factory closures and unemployment in the process of improving efficiency. The gains in efficiency may be widespread in space and time, while the costs will all be met up front, giving an incentive to the losers to protest, but no incentive to the winners to contradict the losers. Hence, restructuring tends to receive bad press both in Europe and the U.S.

It should also be recognized that in the strategic arms subsector (nuclear weapons and submarines and strategic missiles) production runs will hardly ever be long enough to lower unit costs through economies of scale and learning, or through exporting. In addition, producers will not share all the relevant information and capabilities of these highly sophisticated systems with buyers, even if they are allies. The critical importance of these arms for all states that have them — not for their use but for their deter-

105 The Merchant Marine Act of 1920 (with many changes up to 2002), whose promoters declared it, served mainly as a tool to protect injured seaman, establishes that ships that engage in domestic trade should be built and flagged in the United States and crewed by its citizens, thus revealing its protectionist nature. Also, the so-called Buy-American Act, or Title 41 of the United States Code of 1933 (with many changes since), regulating public contracts, is a clear protectionist tool.

${ }^{106}$ David Litterick, "Pentagon Awards Air Tanker Contract to EADS," telegraph.co.uk (4 March 2008); available at www.telegraph.co.uk/money/main.jhtml?xml=/money/2008/03/ 03/cneads103.xml. 
rent power - becomes an insurmountable barrier to totally free trade. ${ }^{107}$ However, this market is just a niche of the overall defense sector (albeit a costly niche), and it does not justify a wide policy of autarky or protectionism.

There have already been some changes within the biggest EU member states in the armored vehicles and warship subsectors, ${ }^{108}$ but they have yet to be restructured at the European level. ${ }^{109}$ Shipyards lag behind other sectors, probably because they focus on the cheapest part of the warship as a weapons system: the platform. On platforms, there are not great economic gains to be had from technological restructuring, and there is not much competition from the United States (competition is tougher with Asia, and in the commercial ships subsector). Of course, there would be gains in economies of scale that could be realized by concentrating production and increasing production runs, but the costs in national pride and unemployment are still too high for governments to accept. Perhaps more important, most shipyards serve military and civilian clients, which have very different requirements and approaches, and they hesitate to establish restructuring priorities. Despite being a lucrative niche, demand is extremely variable, and shipyards try to hedge their bets by maintaining a presence in various segments. However, most big shipyards in Europe are already integrated with other defense companies, like BAe Systems, Thales, and HDW (Germany).

${ }^{107}$ Of course, one could argue whether nuclear weapons really provide any deterrent function, since it is very hard to imagine a Western government using nuclear weapons, due to the devastating consequences they would have not only on an aggressor, but also, sooner or later, on the defender. While in the Cold War the stock of nuclear weapons served to deter the USSR from using them first, the more probable future threats are bodies that are not deterred by nuclear retaliation. New states with nuclear weapons hardly believe the nuclear powers would use nuclear weapons against them, for internal more than strategic or tactical reasons, while they let it be known that they have them to deter aggressors. So states have nuclear weapons to not use them; but to have them creates a doubt, which changes the strategic calculus of a potential aggressor, and that may justify having them (just enough to make the point). See Robert S. McNamara, "The Military Role of Nuclear Weapons: Perceptions and Misperceptions,” Foreign Affairs 62:1 (Fall 1983): 59-80

${ }^{108}$ The most recent development occurred in France, when Thales bought a 25 percent share in DCN, whose control is now shared by the French state and the private company, Thales, in which the French state also holds a 31 percent stake; Thales corporate press release, "Thales and DCN Welcome Brussels Decision on Closer Ties Between the Two Groups," 20 March 2007; available at www.thalesgroup.com/naval/Press-Room/Press-Release-search-all/PressRelease-search-result/Press-Release-Article.html?link=345B536E-480A-3918-1C087346134A3616:central\&locale=EN-gb\&Title=Thales+and+DCN+welcome+Brussels+ decision+on+closer+ties+between+the+two+groups\&dis=1). An important aspect is that the French state could have scuttled the deal under the exception in Article 296; however, it did not and let the deal be evaluated by the ECom under its powers of regulating competition. The two companies only considered the deal done after the ECom approved it; European Commission (ECom), Prior Notification of a Concentration (Case COMP/M.4191 - État Français-Thalès/DCN), 2007/C 35/07, 17 February 2007 (published in OJEU C35/50 17.2.2007).

${ }^{109}$ DAI, Prospects on the European Defence Industry, 32-37. 


\section{European Defense Agency}

There were several attempts within NATO, the WEU, and the EU to create a European armaments or defense agency, aiming at standardizing equipment and procurement and improving interoperability between the allies. ${ }^{110}$ Michel Jobert (former Prime Minister of France), ${ }^{111}$ Leo Tindemans (former Prime Minister of Belgium), ${ }^{112}$ and Thomas Callaghan all at one time or another proposed the creation of a European armaments agency to improve cooperation and reduce weapons costs. Many reports were produced, mostly in favor of the integration of the European defense sector with protectionist trade policies. ${ }^{113}$ A European armaments or defense agency is mentioned in the TEU (Maastricht), but it was only after Le Touquet that France and the UK agreed definitely on its creation. So, in 2004 the European Defense Agency came to life as an intergovernmental EU agency under the authority of the Council, in the CFSP pillar, with headquarters in Brussels. ${ }^{114}$ With the exception of Denmark (which can choose to opt out of the CFSP), all other twenty-six EU member states are full participants in the EDA.

EDA's functions are broad, but very dependent on the Council and the participating states, and must be cooperatively realized by all of them. This will inevitably be a cause of frustration among those that expect EDA to produce effective and rapid results. In short, the main functions of the EDA are:

- The development of defense capabilities, including the identification and harmonization of requirements and the proposal of collaborative activities, for crisis management operations

- The promotion of European armaments cooperation, including promoting and proposing new cooperative projects to meet ESDP requirements, managing specific programs through OCCAR, and promoting cost-effective procurement

- The strengthening of the defense industrial base and helping to create the EDEM

${ }^{110}$ Recall that the Military Agency for Standardization (NATO) and the Standing Armaments Committee (WEU) were the earliest ancestors of the present EDA.

111 See Callaghan, U.S./European Economic Cooperation in Military and Civil Technology, 79.

${ }^{112}$ Leo Tindemans, L'Union Européenne, 1975. He also accepted the idea of integration at several speeds, according to national options. See Urwin, The Community of Europe, 218-21; Zorgbibe, Histoire de la Construction Européenne, 181-96; and Burgess, Federalism and European Union, 106-16.

113 To cite just the most important: Egon Klepsch, Report on European Armaments Procurement Cooperation, European Parliament Working Group 83/78 (8 May 1978); David Greenwood, Report on a Policy for Promoting Defence and Technological Cooperation Among West European Countries, for the Commission of the European Communities (1980); the Vredling Report (IEPG, 1987) of the Independent European Program Group; Terrence Guay, At Arm's Length - The European Union and Europe's Defence Industry (London: MacMillan, 1998), 45; and Aybet, The Dynamics of European Security Cooperation, 160.

${ }^{114}$ Council Joint Action 2004/551/CFSP, of 12 July 2004. 
- The enhancement of the effectiveness of European R\&D efforts (when appropriate, in articulation with the ECom), including promoting research for future defense and security requirements, coordinating and planning joint research, and managing defense R\&D contracts.

Its budget is represented in Table 4, and its manpower is currently about one hundred.

If EDA were to become an operational agency, its operational expenditures, not staff, should be the dominant item. The allocation of operational expenditures to studies and projects, and not contracts or R\&D, suggests that EDA is mostly a state bureaucracy and does not seem to be articulated with OCCAR.

Table 4: EDA Financial Information (EURO million) (source: EDA Financial Reports)

\begin{tabular}{llllllll}
\hline Year & Staff & $\begin{array}{l}\text { Staff } \\
\text { Exp } \\
\mathbf{( \% )}\end{array}$ & $\begin{array}{l}\text { Operat. } \\
\text { Exp* } \\
\mathbf{( \% )}\end{array}$ & Budget & Revenue & Expenses & $\begin{array}{l}\text { Accounting } \\
\text { Surplus }\end{array}$ \\
\hline 2004 & 8 & 72 & 0 & 1.93 & 1.8 & 0.4 & +1.4 \\
\hline 2005 & 79 & 58 & 20 & 21.2 & 20.7 & 12.8 & +7.9 \\
\hline 2006 & 94 & 58 & 21 & 22.3 & 22.7 & 18.8 & +3.9 \\
\hline
\end{tabular}

* Operational expenditure for operational studies and projects.

It has been announced (and EDA has reported in its latest financial statement) that the agency will manage a $€ 55$ million collaborative R\&D program, with a total sum of defense expenditures for all the EU member states of about $€ 193$ billion, of which less than $€ 10$ billion are allocated to R\&D. It is a beginning. But it is not clear why the $€ 55$ million are not included in the EDA budget.

It is still too early to decide on the merits of the EDA. Its website shows its broad priorities: to develop the capabilities and industries to reduce Europe's dependence on non-Europeans in defense equipment and research, and to prepare an armaments strategy. ${ }^{115}$ It is not clear what is to be achieved by EDA in precise terms, or when. That is probably due to the fact that it needs the consensus of all twenty-six participant states, and that makes the process and the results almost impossible to predict, both in time and content.

Perhaps more importantly, the EDA has vague objectives; even worse - it lacks goals. It tries to emulate a state agency, but it does not operate in a state; so the EDA appears to be a fish out of water, and even with the best of intentions the participating

${ }^{115}$ See www.eda.europa.eu/genericitem.aspx?area=Background\&id=324. 
states are not really sure what they want from it. If its mission is to improve the efficiency of the procurement process (defined broadly, including $R \& D$ ), then it is an economic problem and should be in the Communities brief. But it is under the authority of the Council, meaning that it is viewed as a matter of high politics, or at least as something precious to the participating states.

EDA has asserted its opposition to offsets and national protectionism, but the wording suggests that it may support European protectionism, leaving open the question of why protectionism is bad nationally but good for Europe. EDA opposition to protectionism probably explains why the member states (mostly small states, and prone to protectionism) are reluctant to favor a centralization of procurement (again, including $R \& D)$.

So, why do states - or, more accurately, governments - decide it is so important for them to control an agency embroiled in low politics, when they have agreed to pool sovereignty in so many policy areas? Before advancing an explanation, it should be noted that domestic arms agencies have clear goals and procedures, and articulate with other state agencies. Typically, they procure arms for the national armed forces, in line with each state's national security strategy and force plan. ${ }^{116}$ This model has no equivalent in the EU. It is true that the EU has a security strategy, but the institutional setting is not even remotely similar to that of any state; more importantly, the EU security strategy was not followed by the development of a military strategy and a force plan, guided by a coherent set of policy documents to shape defense policy. Without an EU force plan, the EDA is left with a residual area of arms procurement for the participating states. Moreover, being outside of the EU Public Administration, which is under the authority of the ECom, but within a parallel and distinct bureaucracy, under the authority of the Council, it is even more difficult to assimilate the EDA to the form of a domestic arms agency. ${ }^{117}$

Returning to the central question, governments are accountable to their national publics, and not to a European people. With each reduction in sovereignty (pooled or traded for something else), governments permanently lose instruments of political action to deliver results to their national voters, and these people expect to be convinced

${ }^{116}$ That is, the number and composition of human resources and equipment needed to meet the national security strategy, determined by the political decisions of parliaments, heads of state, and governments.

${ }^{117}$ No doubt a fascinating research theme is the emerging duplication of public administrations in Brussels, on each side of the Rue de La Loi: one, under the authority of the ECom; the other under the authority of the Council. 
that this was a wise choice. ${ }^{118}$ So, the fewer levers these leaders have to work with, the higher the marginal value of each sector in line for integration. It is not surprising that governments try harder to keep these levers for themselves, even if they accept the principle of pooling sovereignty. This is what sovereignty means in practice for governments of small states: levers, and the means to get results domestically.

Of course, a more trivial explanation is just that small states fear big ones. Small states only abdicate sovereignty when they are sure to have a real say in future decisions. All this is very much a matter of perception and subjectivity but, despite the transparency of the environment and the openness of the discussions in the EU, it may explain some otherwise incomprehensible protectionist decisions.

Both explanations imply longer negotiations and decision-making processes, more difficulty with integration, and increasingly vague agreements, which would allow every government to extract its own victory or minimize its loss. As is usual in negotiations, a vague agreement just means that the parties are not ready to commit to anything more substantial; to force an agreement on parties that would not reach it freely builds tensions that will come out sooner or later, bringing the agreement to an early end.

In short, perhaps the only way to create the EDA within the EU-an old political dream with a history of its own-was by having it sit idle on the sidelines, while waiting for states to restructure their domestic defense industries, and while searching for its place in the institutional setting, which itself is not a state, and does not seem clear what it really is. Considering the complexity of the entire integration process, one can only expect that it will take a long time for EDA to fulfill its promises, if it ever will.

\section{Specific Nature of the Integration of the European Defense Sector}

For all the economic appeal of the integration process, and for all the gains that could potentially be realized by participation in the EDEM, there are costs to be considered, although many are difficult to quantify. This does not mean that they cannot be considered in an economic analysis, only that they are more subjective and complex. This section will present the path and the steps toward full integration, and thus it will become clear how much progress Europe has made along the path of integration.

${ }^{118}$ It may be very difficult for some governments these days to explain the domestic advantages of the single currency, when people believe the European Central Bank sets interest rates based on the prevailing economic average conditions of the Euro-states, not the conditions of their own state, and they occasionally suffer for that. People in countries that have rates much lower than they had historically (or would have outside of the single currency) rarely think of that, and do not even notice that in their own countries the monetary policy before the Euro had to be set for an average, and some regions lost and others gained from that. In short, governments have fewer instruments to "deliver the goods" to their publics, and have difficulty in being believed when explaining policies. It cannot come as a surprise that governments do their best to keep the few instruments they still have to deliver the goods, these being, mostly, employment and growth. 


\section{The Nature of the European Integration Process}

As discussed above, the process of defense integration in Europe has followed a hybrid path, with a supranational component, through the Communities, and an intergovernmental component, through treaties and regimes used in the other two pillars of the EU and other sectors, particularly in the defense sector. It was also mentioned above that the intergovernmental method of decision-making requires consensus, which takes longer to achieve, than majority decisions applied in supranational bodies.

The integration process started in 1948, in the Congress of Europe in The Hague. At that time, those in favor of supranational structures (known as the federalists) lost, and had to wait until the ESCS was created. The model had been conceived by David Mitrany and was later adapted to the European environment, in a descriptive way, by Ernst Haas: national economies were progressively integrated, sector by sector, by spillover, or engrenage. ${ }^{119}$ Under this view, increasing economic integration was gradually making war less likely, because war was too costly and disruptive to established interests.

Later, Bela Balassa formalized the model in articulated steps that would lead to total integration ${ }^{120}$ :

- Free trade area: This step achieves the free of circulation of goods through the removal of all customs barriers (tariffs, quantitative restrictions, and quotas), but each state retains its sovereignty in dealing with third states. It is a case of negative integration, because it eliminates norms and barriers.

- Customs union: This step goes beyond the free trade area concept by having a common commercial external policy, characterized by common customs tariffs and common trade agreements. To the negative integration phase it adds a positive one, by establishing new norms. The first integration goal of the EEC was the realization of a customs union. ${ }^{121}$

- Single market: The single market goes beyond the previous step by having full liberty of circulation of goods, people, and capital, meaning the removal of all customs and non-customs barriers (such as technical, fiscal, or health standards). Although the EEC was often called the "Common Market,", it was only on 1 January 1993 that it became the Single European Market (and still featured many exceptions, like defense or pharmaceuticals).

- Economic and monetary union: This stage adds a common currency; for fourteen member-states of the EU, at present, it is the Euro $(€)$.

${ }^{119}$ See David Mitrany, A Working Peace System (Chicago: Quadrangle Books, 1943); and Ben Rosamond, Theories of European Integration (New York: Palgrave, 2000), 31-42.

${ }^{120}$ Bela Balassa, The Theory of Economic Integration (London: R.D. Unwin, 1961).

${ }^{121}$ Which it achieved on 1 July 1968, eighteen months ahead of the schedule set forth in the Treaty of Rome (EEC).

${ }^{122}$ For de Gaulle (and Thatcher), “Le Marché commun, c’est un tarif extérieur commun.” Alan Peyrefitte, C’était de Gaulle, vol. 3 (Paris: Éditions de Fallois-Fayard, 2000), 339. 
- Political union: The final step adds a common set of state institutions to govern the new polity and defines a wide range of matters where they will take precedence over individual states' sovereignty. In the defense sector, there should be a common defense policy and a common defense.

Of course, this model derives in large measure from experience, because when it was formulated there was only a program covering the first three steps. ${ }^{123}$ In practice, two more processes exogenous to this model converged in the integration process: the role of the European Court of Justice (ECJ), and bringing into the Communities policies that emerged from outside the first pillar, or even outside of the EU.

The ECJ has been critical to the success of the integration process. For example, it was through ECJ rulings that the principle of primacy of EU law over national law emerged. ${ }^{124}$ This principle has never been challenged in treaty revisions by member states, not even by France or the U.K., so it has become a settled fact (albeit one that has never been clearly stated before the peoples of Europe). It is because it favored a pro-integration interpretation of the treaties that it became widely viewed as one of the engines of the integration process, in a way similar to how the U.S. Supreme Court functioned in its early days. ${ }^{125}$ The ECJ was always careful to avoid pressing too much for integration (and going against the deeply-held views of the member states), with the result that there is some basis for accusations of inconsistency. ${ }^{126}$ That, however, may have been the wisest position: to try and amass the largest possible constituency in its favor (and in favor of integration) or at least not to elicit widespread opposition against its jurisprudence and its existence.

Schengen is the best example of the process of importing policies into the Community: the process and its policy developed outside the EU, growing out of two international treaties between several member states. It was brought into the third pillar, and then transferred to the first. Schengen also represents one example of variable geometry in the EU. Thus, it is an example to consider in relation to defense: both OCCAR and the Framework Agreement (both based on international treaties whose parties are member states of the EU) can, in time, be brought into the EU and even into the first

${ }^{123}$ Based on premises established at the General Agreement on Tariffs and Trade, in 1947 (GATT-47).

124 Starting with judgment Van Gend en Loos of 5 February 1963, in case 26/62.

125 "The Court is generally regarded as one of the most 'European-minded' institutions in the Community”; Trevor Hartley, The Foundations of European Community Law, $4^{\text {th }}$ edition (Oxford: Oxford University Press, 1998), 54. “And, as with the Supreme Court in its more expansive moods, ECJ decisions have often reflected a clear federalist ideology"; "Who Killed the Constitution?” The Economist (20 December 2003). This, of course, was a major reason for including it in the Communities from the outset, since these were inspired by the federal model of the United States.

${ }^{126}$ Examples of caution were the judgment in Commission v. France of 9 August 1994, on case C-327/91; Opinion 1/94 of 15 November 1994; Opinion 2/92 of 24 March 1995; Opinion 2/94 of 28 March 1996; and judgment in Commission v. United Kingdom of 12 May 1998, on case C-106/96. See Hartley, The Foundations of European Community Law, 158-70. 
pillar, even if they are incorporated in an Enhanced Cooperation framework that is not binding to all member states.

The process described above may not have any additional steps, but it is a safe bet that it will take a very long time to move from the fourth step (economic and monetary union) to the fifth (political union). Simply following the example of the United States may not be the best course of action, given that a devastating civil war was needed to decisively establish the federal political union in the United States.

\section{Security and National Defense}

All actors in economics and politics pretend that the sector they operate in is different from all others, and in a narrow sense they are all correct. But the defense sector has specific aspects that truly differentiate it from all other areas of state action.

The first issue is that defense is the very essence of the nation-state; as Max Weber stated, the state is a political enterprise whose defining characteristic is that its administrators uphold a claim on a monopoly on the legitimate use of violence. ${ }^{127}$

Sovereignty is also part of the essence of the state: all states are equal in this regard. ${ }^{128}$ Internally, the state does not recognize any authority above or even equal to itself, in particular with respect to the competence of auto-organization (called, in German, kompetenz-kompetenz).

In Weber's widely accepted definition, one can separate the provision of the means to apply force from the technical use of force. In addition, Weber did not argue that the means by which force is applied are part of the essence of the state, only the power and responsibility to decide to apply force. This is not a mere academic note. Some novelties, like state contracts with private military companies, pose a challenge to the traditional (albeit historically recent) view of the state, but do not conflict with the essence of the definition above. Likewise, the essence of the state is undamaged by engaging private defense firms. Nor is it damaged by a free trade in arms between allies (with the limits recommended by security concerns). Of course, these novel options have disadvantages, as do the more traditional approaches; the novel options are just more adapted to a globalized world, where scarcity of resources is the norm that demands that states do more and better with less.

The reasons that best justify internalizing the three areas just discussed within the state are efficiency and criticality. Often they have to be balanced against each other, because they present opportunity costs to all states; even so, criticality usually takes precedence over priorities when states face existential threats. Their relation to internalization is as follows:

- Efficiency: If the overall cost to a state of producing something itself is bigger than by getting it done from a contractor, it should not internalize the task; all costs and benefits have to be taken into account with a view of the entire

${ }^{127}$ Max Weber, Économie et Société, in two volumes (Paris: Pocket, 1995 [1914]), 1:97.

128 This was elevated to a general principle in the United Nations Charter (Article 2, paragraph 1). 
country in mind, even those that are hard to quantify (the state serves the country as a whole, and not any one sector in particular, however important).

- Criticality: For example, in order to defend itself from aggression, a country's economy may have to be transformed into an integrated logistic system to support the war effort. This may require that factories come under state command and control, since their production is critical in achieving the desired result of defeating imminent threats or aggression. Criticality also includes secrecy. For example, a specific technological solution may provide a critical advantage against a threat, or a country may have a grave vulnerability and should wish to conceal it from threatening opponents.

All producers of sophisticated arms have restrictions on the technology they are authorized to transfer to buyers-even if the customer is a loyal ally of the firm's home nation ${ }^{129}$-because the state where the firm is located has concluded that some technologies are genuinely critical, and do not want to share them and potentially lose some strategic advantage.

One can still argue that the national firms have better reasons to serve the pillars of their own state (as is the case with all matters related to defense), even if only for emotional reasons, thus justifying national (or European) protectionism. Of course, if such a preference is internalized within the people involved, then there is no need for state rules, because their decisions will freely reflect a national (or European) preference. If there are protectionist norms in place, however, that means the first choice that people would make is not for the national (or European) option, so states or the EU have to impose it.

The case of each state accepting only its own nationals as members of its armed forces is not a universal rule, and regulations in this regard may become more flexible in the future, and maybe in more ways than simply implementing provisions around contracts with private military companies. ${ }^{130} \mathrm{EU}$ member states have not contracted with private military companies to the same extent that the United States has, but the resource constraints that led the U.S. along that path may become too compelling for Europe to resist. This outcome may be even more likely given the further constraint that Europeans (if one believes the media reports) are less willing to accept casualties in conflict situations, particularly if these soldiers are their own nationals.

${ }^{129}$ For one, differences in interests may lead to states being in different camps in the future (although, if two nations' interests are so different, then one could wonder why and how they are cooperating together in a far-reaching defense alliance. The reason that states resist allowing national defense firms to sell their products to other nations may just be mistrust and fear that the technology might end up where it should not.

${ }^{130}$ There are already foreign corps in the armed forces of some countries, like the Foreign Legion in France, the Gurkhas in the U.K., or the Legion in Spain. Even further, since 2001 Spain has been recruiting foreigners into its armed forces (mostly South Americans) for jobs that do not require specialized skills. See, for example, http:/www.clarin.com/diario/ 2001/06/12/i-02801.htm; or http://www.eldiariomontanes.es/prensa/20070626/nacional/ nueva-legion-extranjeros-puebla_20070626.html. 
Finally, it is difficult to understand why Western states-which have for so long declared their intent to solve their conflicts without the use of force and have a long and successful defense alliance-still have such difficulty in sharing their defense assets. For example, why do some Western states resist having their military forces under the command of officers from other nations? And why do they reject the formation of a single market in arms? These phenomena suggest that there is still some mistrust, as this quote from 1990 illustrates: "No big European country is yet willing to let the core questions of defense-who organizes the armed forces on our soil, and who orders them into action?-be decided anywhere else than in its own capital. ... A single European defense policy is not coming soon." 131 Even so, the continual roll call of new multinational defense structures in Europe-Eurocorps, Eurofor, Euromarfor, the battle groups - show that there is a clear drive toward integration underway, even if each of these structures individually are small forces and in some ways exceptional.

Distinct national strategic goals are also at the root of the reluctance to integrate. For example, the U.K. and France have nuclear weapons and, understandably, want to preserve control of the deterrent effect they offer. Also, some EU states have privileged relations with their old colonies (like the U.K., France, Portugal, and Spain) and want to preserve those relations, for reasons of both economic and national power.

No matter how much each country might wish to have full strategic autonomy, in the age of globalization this is impossible to achieve in full. As stated above, certain critical aspects can be internalized, but even the cost of only internalizing those areas directly related to security is excessive at present, and it is even more burdensome to organize a nation for a permanent state of war. The result of such an effort would be a command economy, and it would collapse like the USSR.

So each state has to find a balance that minimizes its risks and vulnerabilities (accepting there will always be some of both) and comes at a reasonable cost. In terms of preserving autonomy over the arms and equipment for its armed forces, the solution is to ensure security of supply, which most likely cannot be achieved by producing everything in the state or under a protectionist regime. Applying this to the EU and its member states, it would appear that a better solution than the insistence on either national autonomy or the "fortress Europe" mentality is to promote competition in the several subsectors of the defense industry. There may be problems when demand is too small to sustain competition in the European or global markets, but this poses fewer challenges than the duplication of defense industries.

Apart from some very limited critical niches, cultivating the widest possible competition is the option that best serves the interests of buyers. The apparent vulnerability of a state depending on a private company in a competitive market for arms and equipment may appear to be serious, but in effect is robust in important aspects. The first such benefit-and one that is often overlooked-is that critical production facilities are high-value targets for an opponent; the less there are of them, the higher the level of protection is required (and the higher the cost), and the bigger the loss if a fa-

131 “Survey - Defence and the Democracies,” The Economist (1 September 1990): 19. 
cility is damaged. Second, with multiple, geographically separated suppliers operating in a market, there is redundancy in supply. Third, since the various suppliers that are in competition all depend on their customers to remain operational, they have to serve their buyers' interests, contrary to the example of many national defense firms, who know that they have a guaranteed stream of business.

In short, in a globalized world with acute resource scarcity, strategic autonomy (meaning having sufficient national capacity to enable a state to not depend on others) is simply too costly, as well as being of doubtful effectiveness. The alternative is to ensure security of supply from competing suppliers.

\section{Limits to the Free Trade in Arms}

The trade in arms is different from most other trade because it is not free; in general, arms can only be sold across borders with export permits, even if the seller is a state and not a private company. ${ }^{132}$ This holds true for both small arms and large weapon systems. So, if all governments agree to follow the same rules of transparency, it is a totally controlled trade.

It is also a special case in that the client of a defense firm is a government. In fact, the government is often the only client of a national supplier, particularly one that the government regulates or owns. Another characteristic that is specific to the arms trade is its involvement in the competition between governments. As a result, the functioning of the defense industrial sector was for a long time mostly hidden from public view, but privatization and taxpayer pressure are working to make the operations of the sector more transparent.

Of course, arms are critical tools of power: those who have them may impose their will on others. For example, people with arms can bring about change in the people who are in government; people with arms can also resist abuses by their government. So it is not arms, but rather people, and the use they make of arms, that are the critical elements to consider when reviewing the arms trade. It is for this reason that the EU has established export controls that are heavily dependent on the buyer and the intended use of the arms (i.e., trade is limited to EU member states and other states that are party to various international treaties and non-proliferation regimes).

One issue to note at this point is that the goal of improving national defense industries may conflict with the goal of non-proliferation. This is both the case internally, because most states do not want their citizens to use force to solve conflicts among themselves, and even less to oppose state authorities, as well as externally, because most states prefer to sell arms to friendly states and organizations, and not to those that may in the future turn against the seller or use the arms to cause humanitarian crises.

An even more specific point to consider is the fact that some weapons are so potent that there is no room for mistakes, which is why WMD require even stronger levels of regulation and control. And since these weapons can be fabricated from dual-use goods, such controls have to be applied to apparently innocent civilian goods. But most

${ }^{132}$ Both the pharmaceutical and chemical industries have their trade regulated within the EU as well. 
of this regulation can, in practice, only be performed on items that are crossing borders or are in the possession of suspicious characters.

\section{Prospects of the Defense Sector and European Integration}

It is always hard to predict future policies and policy results, but it is even more difficult when the decision-making process involves not just one national process but twenty-seven national processes. However, it seems safe to predict that, whatever the end result of the integration process will be, it is not going to happen soon. There is now (and will be for years) a significant level of uncertainty about where the EU is and where it is heading.

In the section below, I analyze the preferences of the main actors of the defense sector regarding defense integration. It does not make sense to aggregate or weight such preferences; the goal of the analysis is to try to anticipate reactions to policies. The next goal is to analyze possible future scenarios for integration in the defense sector.

\section{The Actors' Preferences}

The first actor to be analyzed is collective: the defense industries. National and European champions tend to prefer integration, because they would then be regarded as "too strategic to fail," which would render them invulnerable. This conclusion may apply to managers and some other employees, but it would not protect unskilled workers, because their jobs are low-paying and not protected. Small and medium-sized companies may prefer integration, because they would gain automatic access to wider markets and opportunities, although they would also face a higher level of domestic competition. Still, more sales should translate to growth for such firms.

Another important actor is the High Representative (to be Vice-president of the ECom). He should be clearly in favor of defense integration, because he would find his powers increased, including in the Communities. In fact, his new position as defined under the Treaty of Lisbon-to coordinate supranational and intergovernmental processes - spells out this increase in authority perfectly clearly.

The ECom is, by the nature of its mission (which is to develop the Communities) the most solid supporter of integration, and has often displayed this support in its papers and positions on defense. The change in the composition and size of the ECom established in the Treaty of Lisbon should not change the essence of its position, but should give the bigger states more control over the integration process, enabling them to advance it further when it suits them.

The European Parliament (EP) has been one of the main supporters of defense integration (along with the ECom), as should be expected from its direct election and its role. But direct election may produce different results-and even some potential surprises-in the future. On the other hand, the EP has much less power than the national parliaments. So even though there is a (small) margin of uncertainty about the future positions of the EP, it is unlikely the EP will actually be able to change much of the process, whatever it is. 
The ECJ is a special actor, and it may even be controversial to include it in this analysis, since it does not take positions on policies, unless one tries to deduce them from its sentences and opinions. Including the court in this discussion, however, reveals the crucial role that the ECJ has played in the integration process. ${ }^{133}$ It is important to keep in mind, though, that the ECJ has oscillated; while its decisions have more often than not helped to promote the integration process, it has also been careful to avoid decisions that would generate strong opposition from governments or damaging tensions.

The European Council and the Council of Ministers are intergovernmental organs, but they work for the Communities in some instances. Thus, they are divided in their approach, and decide on a case-by-case basis.

National governments are a collective actor domestically (albeit often dominated by a global vision or a head of government) and act collectively in the Council, but they have distinct priorities and preoccupations, not least with specific election cycles and policy concerns. It is consistent with past experience that small states tend to be more protectionist and oppose the restructuring and integration of the defense sector, because their governments would irrevocably lose levers of power to the bigger states, without receiving adequate compensation. It should be noted that many small states see in the ECom an ally in the integration process, and many big states take just the opposite view. Hence, defense integration in the Communities could have the support of small states, but it is more difficult for bigger states (and certainly for the U.K.) to accept supranational decisions in such a critical sector. That is why the larger European states pursued defense cooperation outside of the EU in the Framework Agreement, Eurocorps, and OCCAR. In short, for small and big states to agree, either they have to develop the will to find common ground through negotiation, or the winners in the integration process have to agree to adequately compensate the losers. The latter prospect in particular has been thus far constantly out of reach, because of budgetary constraints related to the single currency.

A government will only decide to abdicate some of its sovereign powers in a particular policy area-whether through giving up its powers or by an arrangement of pooled sovereignty with other states-if they conclude that they will gain by doing so. That is, a state will only surrender part of its sovereignty if it concludes that the benefits of doing so will exceed the costs, according to their analysis. As Terrence Guay has written, "After each round of integration, member states protect sovereignty in those policy areas that are functionally linked to areas subject to integration. When these interventions become too costly and counter-productive, states will end their mutual competition in these policy areas by agreeing to integrate further at the EU level."134

${ }^{133}$ As already referred to above, the principle of the primacy of European law was established by jurisprudence.

${ }^{134}$ Guay, At Arm's Length - The European Union and Europe's Defence Industry, 183. See also Dorette Corbey, "Dialectical Functionalism: Stagnation as a Booster of European Integration,” International Organization 49:2 (Spring 1995): 253-84. 
There is also potential for controversy, since these evaluations depend in some measure on who is producing them, and for what audience. It is perhaps unavoidable that a government will produce evaluations that serve above all the political interests of the people in power (and for good reason, since the people who conduct such analyses have to satisfy those that support them). This view differs from the pleasing, ideal, abstract vision of how governments should operate, but it is closer to reality than an abstraction, and thus may help to produce better explanations.

Another collective actor is the national public administration of each state. Their role is very important, because they have the technical knowledge to prepare and implement policies, and also the capacity to shape governmental agendas, but they are rarely analyzed in this light. Public servants (including military personnel) are educated and trained to serve their country, so it is hard for them to serve other entities, not least those that are supranational in nature. In practice, this means that a state will have to wait for a generation or two of turnover in its public administration to start having its public servants thinking in terms of what best serves Europe as a whole, instead of considering first and foremost the national good. Younger generations may adapt easily to this new way of thinking, but they are under the authority of people educated under the earlier system, who are used to a mindset that places primacy on defending their country. The conclusion is that it is unlikely that the national public administrations will support the integration process (least of all in the defense sector), except perhaps in the six founding member states of the Communities, where integration is fifty years (and two generations) old.

Taxpayers and citizens also play a crucial role in this matter, because they elect governments and react to policies. They are perhaps the most heterogeneous group considered so far in this analysis. But it seems reasonable to assume that centralization would detach them from decisions, reducing their sense of shared responsibility and inclusion that is so important in democratic states. On the other hand, it does not appear that participation in the defense sector is the citizenry's top priority in the nations under consideration here, so centralization (if governed by the adequate democratic control mechanisms) should not be bad. For taxpayers, more efficient use of public resources holds obvious advantages, including allowing for more and better arms. All in all, citizens should as a general rule be in favor of defense sector integration, except when they are losers in the restructuring processes or have strong nationalist or patriotic views.

In short, the ECom and the EP will push for continued integration, and governments will only let the process proceed when they have calculated that the benefits they can offer to their domestic audiences will exceed the costs in lost tools of domestic political action. Without a major change in the situation-e.g., an exogenous shock or the appearance of strong European leaders - this means that the costs and benefits of integration as they are perceived by national governments are broadly the same, and the integration process should proceed very slowly. 


\section{Future Scenarios}

The EU has often and consistently declared that it is a power, that it has interests in world affairs, and that it is willing to pay to pursue them. ${ }^{135}$ So far these claims are credible in domains like soft power and humanitarian aid. But in the area of hard (or military) power, the situation is closer to Eurosclerosis, as Europe's period of economic decline was called in the 1970s.

To be a credible and effective actor in world affairs, the EU needs power, which is the product of two factors: capabilities and will. Thus, there will be no power if either factor is close to zero. ${ }^{136}$ The EU needs power across the entire spectrum of potential scenarios, because in world affairs it will encounter all strategic situations. And the EU needs the ability to project power to distant places, which is one context in which military capabilities are critical. The EU is short on capabilities and the political will to use them; so, it has currently little power (or only soft power). To return to a multilateral discourse, the U.S. recently expressed the wish that the EU would increase its hard-power capabilities, only this time without the usual caveat of duplication, suggesting instead a more equal relationship. ${ }^{137}$

If the EU and its member states really believe in what they declare, they have to increase their efficiency and be determined to obtain the resources needed to pursue their declared worldwide interests. To be more specific, the EU needs to integrate more and to allocate more resources to defense. It may do one or any combination of three things to increase the resources available to defense:

- Substantially increase the rate of economic growth. This is a medium-term solution, but it has not been too effective in the recent past, although not for lack of trying. In fact, EU economies seem too rigid to depend on this option for rapid results.

- Transfer resources from other sectors. With defense consuming on average 1.5 percent of the EU GDP (as opposed to 8 percent for health, and 5 percent for education ${ }^{138}$ ), an increase in defense spending should not be too damaging to other sectors, except that public opinion tends to oppose such a measure, perhaps merely because no convincing explanations have been offered (nor are there any great leaders to offer them).

${ }^{135}$ It suffices to mention the strategy espoused by the European Council in their Presidency Conclusions from the Lisbon meeting (23-24 March 2000).

${ }^{136}$ Robert Art, “To What Ends Military Power?” International Security 4:4 (Spring 1980): 6.

${ }^{137}$ It is remarkable that the United States' permanent representative to NATO, Victoria Nuland, gave two similar speeches within the space of four days (in Paris on 22 February 2008 and in London on 25 February) encouraging European leaders (particularly those in France and the U.K.) to develop EU defense capabilities. See Victoria Nuland, speech to the Press Club of France and the American Chamber of Commerce,” Paris, 22 February 2008; available at http://nato.usmission.gov/Article.asp?ID=21A35613-E9D6-431D-9FD5-36FDD1389EB0; and Nuland, speech at the London School of Economics, London, 25 February 2008; available at http://nato.usmission.gov/ambassador/2008/Amb_Nuland_022508.htm.

${ }^{138}$ Round values based on ECom information. 
- Increase efficiency in the defense sector. This should produce results in two years' time through the harmonization of requirements, pooling of resources for $R \& D$, and common procurement. This would seem to be the easiest option of all, except for the short-term social costs of unemployment and industry restructuring, both of which tend to generate bad press and low poll numbers. ${ }^{139}$

It is probably easier to solve the problem of capabilities than the problem of will in the formula offered above for generating power: having the resources, it is a matter of procuring, integrating, and using the new systems. But will consists of much more than political declarations; it requires that the people follow a political vision. Political will is without question a complex problem, due to its dependency on long-term commitments, which can be disrupted by things like electoral cycles. It is also difficult to achieve political will due to the difficulty of persuading the citizens in European nations that such will is necessary - citizens who are often highly skeptical of their politicians, and are so rich that they believe they can be insulated from any troubles anywhere in the world.

I cannot predict the future, but I can suggest what broad shape the defense sector will have in five years time. I will propose three scenarios, in the approximate sequence in which they might occur over the long term:

- No integration, only intergovernmental cooperation (this is the trivial scenario, representing no real change)

- Some integration, and some intergovernmental cooperation

- Deep integration, with small areas reserved for individual governmental action.

If the long-term evolution process is to continue according to the tendencies of the past, a fourth scenario would be a United States of Europe. This notion is obviously too far-fetched, and of no analytical value.

But there are two notes to be made about the three broad scenarios listed above. In an environment of intergovernmental cooperation, national governments still have certain relevant powers and it seems reasonable to assume that the area of defense and the armed forces would be one of the last powers that a government would agree to give up or share. ${ }^{140}$ Furthermore, it is inconceivable that France or the U.K. would abandon or share control of their nuclear weapons with a supranational and unelected

${ }^{139}$ It is hard these days to put such problems in perspective before voters: "A politician seen as heartless towards 500 workers risks punishment by millions of watching voters." "Winners and Losers," The Economist (1 March 2008): 35.

${ }^{140}$ This is still a risky prediction because of the inclination of European governments to avoid defense spending, except when it can be clearly associated with civilian benefits and a guarantee can be made that it will not lead to any casualties. In fact, this was traditionally one of the last redoubts of sovereignty (if not the absolute last), although that may be less the case in a post-modern Europe. See Robert Cooper, The Breaking of Nations: Order and Chaos in the $21^{\text {st }}$ Century (London: Grove Press, 2004). 
EU authority. Since it is extremely unlikely that we will have a federal democratic Europe for decades to come, there will be areas that national governments will not soon abdicate, and control over nuclear weapons will be most likely the last to be shared.

No Integration, Only Intergovernmental Cooperation. This is the default or current situation, in which defense is mostly a national policy, excluded from the SEM in the relevant treaties. This was confirmed in 2007, in Article 346 of the Treaty of Lisbon, and it shows that governments do not intend to bring defense under the rubric of the Communities anytime soon. It also shows that there was no consensus among the governments on giving up control over the levers of power in the defense sector. The nature of EDA and the way it is working also suggest strongly that enough governments still prefer to have direct control over the defense sector, and over domestic defense industries in particular.

This means that fragmentation, inefficiency, and interoperability problems will persist, while the gap between EU and U.S. capabilities continues to widen, and while EU credibility and power in world affairs will continue to decline. Fundamentally, it suggests that the EU lacks the will to be a power on the global stage. It also results in an avoidable division of labor in world affairs: the EU focuses on economics and low politics, with the advantage of not having to face the prospect of European soldiers coming home in body bags, but it has little capacity of influence. Under the prevailing set of assumptions, Europe is less than the sum of its member states. There is no doubt that many Europeans would accept this rather limited position of the EU, if not outright prefer it. If Europeans are not offered convincing reasons why the EU should be a world power, in all its dimensions, it is not surprising that they might rather be left alone in peace to enjoy their stupendous national wealth. But how long will this choice remain an option?

Some Integration, but Still Some Intergovernmental Cooperation. In this scenario, most institutional defense economics would take place within the context of the Communities, with a functioning EDEM and subject to the governance of the SEM. Schengen is an important precedent, showing that it is possible to create a process by international treaty outside of the Communities that can be adopted by the broader community when there is consensus and the time is right.

There are numerous options to have some (as opposed to none or total) integration in the defense sector, and some of these options may be combinations of simpler ones. Here I will address only a few of these choices. The first is to bring the EDA into the Communities and focus it on arms procurement (to exploit the economic benefits offered by a single market) and on R\&D (by pooling resources from member states), so that more sophisticated projects and programs become viable. The practical implications of this option would be the harmonization of requirements and specifications of at least some arms procured by the member states, either representing the whole EU or certain variable geometry configurations.

Like all forms of integration, it forces member states to negotiate compromises to explore economic gains that allow savings or better acquisitions, whether in quality or quantity. Compromises are always unavoidable, even on purely national projects; the 
cost of arms is currently so high, and still growing so fast, that national security priorities are also giving way to cost considerations. Therefore, integration is unlikely to impose solutions that conflict too much with national culture and habits, but the will to reach a solution acceptable to all is essential.

With EDA in the Communities, OCCAR may stay outside or come into the Communities framework and combine with EDA, emulating an equivalent national agency. If OCCAR stays outside, it may still succeed at its task of obtaining arms or delivering services to its participant states, allowing only one contract for each common weapon system. Remaining outside the Communities might give OCCAR the advantage of not becoming a bureaucratic public agency.

The second step, beyond that just outlined above, is that of common procurement for most arms, which would represent the final stage before a common defense policy, at least in terms of arms. The difficulties are qualitatively the same as in the previous option, although they differ in scale (as do the benefits, particularly in terms of the potential economic gains).

The step, which is desirable in itself, is the creation of a transatlantic defense market - that is, a free trade area in arms within all NATO member states. In other words, in this step there would be no protectionism for defense industries, neither domestically nor regionally. This step implies further industrial restructuring, especially in those subsectors of the defense industry that are currently lagging (warships and armored vehicles), as well as across the borders of small states. Negative impacts on regional economies and on employment are to be expected, which should be addressed with requalification programs like the KONVER and the PERIFRA. The current economic situation in Europe of moderate growth is favorable for these restructuring and requalification programs, but the margins for such public spending are not large.

All the steps above are possible even if the defense exception is kept in the treaties as the safeguard that was originally intended. But the governments should commit themselves to not take advantage of it. If these steps are followed (and, most critically, if the individual states can muster the political will to commit to them), an international custom could form through repeated and consistent practice, easing the widespread internalization of the free trade in arms across the EU without involving either the ECJ or the ECom in the process.

To resist the temptation of having a tool available and not using it-even when it might be so useful in domestic social or industrial policy - will be a tremendous test of the political will of the EU governments. As usual, this is the most difficult requirement. But how long can Europe wait for the will to develop?

Deep Integration, with Areas Reserved for Governments. The more challenging (and more long-term) scenario is that in which the states are left with exclusive powers in matters relating to their own survival (e.g., nuclear weapons), but where all other aspects of national defense become part of a common European defense policy. More than political will, this scenario requires profound trust. But we should not assume that such trust is impossible, since what did European states place in the U.S. or in NATO during the Cold War if not a deep trust that its security would be preserved? 
As already suggested, it is not a matter of trust, but of governments not losing control over certain domestic levers of power. There have to be significant visible benefits for governments to display to their domestic audiences if they are to successfully persuade the public of the wisdom of abdicating or pooling certain elements of domestic sovereignty in favor of integration.

For there to be any significant change in this regard in the future, there needs to be either an exogenous shock that affects Europe or a new generation of European leaders, so that a quite different calculation of costs and benefits emerges and is accepted. A terrorist attack with WMD, a pandemic, a major surge in immigration from a neighboring failed state, or even extreme and sustained weather effects - all would generate widespread social upheaval in Europe, and all are significant threats that would have very serious consequences. Yet they would also offer significant opportunities to make a clearer case for integration.

It is quite difficult to imagine the integration process accelerating-particularly in the defense sector-without a sea change in European politics. Although no sane person wishes for a cataclysm, they are nonetheless possible, and if one happens, accelerating integration is a response that should be considered and advanced. After all, the process of European integration received its initial impetus from a cataclysm: the Second World War.

Conversely, an integration process that takes place too rapidly, without a new and widespread balance of costs and benefits, can itself bring a shock, perhaps even resulting in the use of force by those who strongly oppose the pace of the process, or who reject it outright. The consequence of such a response would most likely be the disintegration of the entire process and its structures.

This is the most important point about this scenario. Of course there will be economic gains, and they will help secure European power in the world, but this was already clear from the discussion above. More integration will mean more compromises, but only integration (and only if it is done when the time is right) can permanently increase Europe's efficiency in providing for its own defense.

\section{Conclusions}

Before World War II, France, Germany, and Great Britain were empires at about the same level of development. After World War II, however, they were in ruins and powerless; only the United States and the Soviet Union were world powers. With the support and incentives of the U.S. in the wake of the war, Europe embarked on an experiment of integration - one that began in the realm of economic cooperation, but that progressively evolved to political and strategic integration. Sixty years later, with Europe still enjoying the longest peace it has known (except for the Balkans, which are hardly central to the idea of Europe), the integration process is firmly entrenched on the level of high politics, with cooperation and integration finally taking place in the defense sector. Hesitations and long decision-making processes are rarely followed by retreats; the fall of the EDC in 1954 or France's electoral derailment of the Constitutional Treaty in 2004 were more rejections of specific courses or paces of integration, 
rather than of the larger concept. The history of European integration shows the centrality of French politics in the process, more than the U.K.'s, whose opposition to supranational arrangements and preference for liberalism has been known since the Congress of Europe in 1948, and was probably the main reason for De Gaulle's vetoes.

Our frustration that even now, after sixty years of integration, fragmentation, duplication, and protectionism remain in the European defense sector should be contrasted with what has already been achieved among peoples whose conflicting traditions and cultures often resulted in bitter enmities that endured for centuries. Eurocorps, Euromarfor, EDA, OCCAR, or the battle groups show genuine, albeit cautious, willingness of their participating member states to advance the integration of their defense sectors. From the point of view of implied loss of sovereignty, the enormity of a nation's decision to put its military forces and personnel under foreign command must not be underestimated.

It should be recognized that most attempts to speed the pace of the integration process in defense have been unsuccessful. On the other hand, intergovernmental cooperation-both inside and outside of the EU-has advanced greatly, implying that governments still prefer the more robust (and more legitimate) consensus approach in the realm of defense to majority voting, and do not yet want the ECom or the EP to decide on defense matters for them. If they change this position, the intergovernmental processes can always be brought into the $\mathrm{EU}$, as was the case with the Schengen Agreement.

The European Union's economic power has not been matched by a commensurate level of influence as a global actor. Frequent disagreements on world affairs between EU member states and a shortage of hard-power capacity contrast with the EU's lofty declarations of its ambitions as a security actor.

The integration of the defense sector, which has mostly been carried out in the realm of low politics, is essential for the EU to improve the hard-power capabilities that it will need to be a credible actor in world affairs, which is a goal of high politics. Pooling resources for the research and development of new weapons systems, the harmonization of weapons requirements, common procurement procedures, and a transatlantic defense market should bring economies of scale and learning (more efficiency) and improve interoperability (more effectiveness). These increases in efficiency and effectiveness should allow the Europeans to have more and better arms, with the same overall outlay of (pooled) resources, thus increasing Europe's capabilities.

To have the power needed to be a credible actor on the geostrategic stage, though, the EU also needs the will to advance these integration steps and to use the capabilities that it develops. It appears that, at present, most Europeans are satisfied with their position in world affairs, and are neither particularly willing to intervene more in global conflict situations, nor to accept the consequences of a higher European profile in the world. Unless the balance of costs and benefits - as calculated by both governments and peoples of Europe-changes significantly, perhaps in reaction to an exogenous shock or a change of leadership, it does not seem likely that Europe will soon display the political will to push for a faster pace of integration in defense and the development of more meaningful capabilities in the area of hard power. In short, it appears that the 
European defense sector will not experience much additional integration in the next five years, leaving a gap between Europe's political declarations and its influence-a disconnect between word and deed-in world affairs. 


\section{THE QUARTERLY JOURNAL}

\section{Bibliography}

A Secure Europe in a Better World - The European Security Strategy. Brussels: European Council, 2003.

Analyse de la Notion de 'Gap' - Le 'Gap' Transatlantic In Research and Documents. Paris: Fondation pour la Recherche Stratégique (FRS), 2002.

Art, Robert. "To What Ends Military Power?" International Security 4, no. 4 (1980): 6 .

Ash, Timothy Garton. Free World. New York: Random House, 2004.

Aybet, Gülnur. The Dynamics of European Security Cooperation, 1945-91. London: Palgrave, 2001.

Balassa, Bela. The Theory of Economic Integration. London: R.D. Unwin, 1961.

Barnier, Frédérique. "Les Transformations des Relations entre l'État et les Producteurs d'Armement: le Cas de GIAT-Industries." In État et Firmes d'Armement en Europe, 107-16. Vol. 22. Paris: CIRPES, Collection Cahier d'Études Stratégiques, 1998.

Bélanger, Yves, and Jean-Paul Hébert. "BAe Systems au Coeur du Processus de Globalisation de l'Industrie de Défense." Arès 19, no. 47 (2001): 41-54.

Bendiek, Annegret, and Hannah Whitney Steele. "The Financing of the EU's Common Foreign and Security Policy." Stiftung Wissenschaft und Politik 16 (2006): 1-7.

Bishop, Paul, and Rose Gripaios. "The Regional Impact of Cuts in U.K. Defense Spending." Defense Analysis 11, no. 2 (1995): 175-87.

Blunden, Margaret. "France." In The Foreign Policies of European Union Member States, 24. Manchester: Manchester University Press, 2000.

Burgess, Michael. Federalism and European Union: The Building of Europe, 19502000. London: Routledge, 2000.

Callaghan, Jr., Thomas A.. U.S./European Economic Cooperation in Military and Civil Technology. Washington, D.C.: CSIS Press-Georgetown University, 1975.

Cooper, Robert. The Breaking of Nations: Order and Chaos in the 21st Century. London: Grove Press, 2004.

Corbey, Dorette. "Dialectical Functionalism: Stagnation as a Booster of European Integration." International Organization 49, no. 2 (1995): 253-84.

Damm, Carl, and Philip Goodhart. The Eurogroup. Brussels: North-Atlantic Assembly, 1972. 
Darnis, Jean-Pierre, G. Gasparini, C. Grams, D. Kehoane, F. Liberti, J.P. Maulny, and M.B. Stumbaum. Lessons Learned from European Defence Equipment Programmes In Occasional Paper. Paris: WEU-ISS, 2007.

De Vestel, Pierre. Defence Markets and Industries in Europe: Time for Political Decisions? In Chaillot Paper. Paris: WEU-ISS, 1995.

European Defence - Industrial and Market Issues. Towards an EU Defence Equipment Policy. European Commission (ECom), 2003.

European Defence: Ready or Not. The Economist (2003): 29.

Everts, Steven, and Charles Grant. Mission Impossible? Managing the Growing Divide Between Europe and the US. London: Centre for European Reform, 2002.

Everts, Steven, L. Freedman, C. Grant, F. Heisbourg, D. Keohane, and M. O'Hanlon. A European Way of War. London: Centre for European Reform, 2004.

Facon, Patrick. "Le Projet de Programme Commun Européen Aéronautique du Général Léchères, 1950-1953." In Historie de la Coopération Européenne dans L'Armement, 17-25. Paris: CNRS Éditions, 2004.

Gordon, Philip. "Their Own Army?" Foreign Affairs 79, no. 4 (2000): 14.

Grant, Robert. The RMA - Europe Can Keep in Step In Occasional Paper. Paris: ISSWEU, 2000.

Guay, Terrence. At Arm's Length - The European Union and Europe's Defence Industry. London: MacMillan, 1998.

Hartley, Keith, and Andrew Cox. The Costs of Non-Europe in Defense Procurement. Main Report. Brussels: European Commission-DGIII, 1988.

Hartley, Keith. "The Future of European Defence Policy." Defence and Peace Economics 14, no. 2 (2003): 107.

Hartley, Keith. NATO Arms Co-Operation. London: George Allen \& Unwin, 1983.

Hartley, Trevor. The Foundations of European Community Law. 4th ed. Oxford: Oxford University Press, 1998.

Hébert, Jean-Paul. "D’Une Production Commune à Une Production Unique? La coopération Européenne en Matière de Production d'Armement Comme Moyen de Renforcement de l'Autonomie Stratégique Européenne." In Historie de la Coopération Européenne dans L'Armement, 200-17. Paris: CNRS Éditions, 2004.

Hébert, Jean-Paul. "L'Européanisation de l'Industrie d'Armement et l'Autonomie Stratégique de l'Europe." Arès 19, no. 48 (2002): 45-59. 


\section{THE QUARTERLY JOURNAL}

Hitch, Charles J., and Roland N. McKean. "The Economics of Defense in the Nuclear Age." Cambridge, MA: Harvard University Press (1967).

Hogan, Michael. "American Marshall Planners and the Search for a European Neocapitalism." American Historical Review 90, no. 1 (1985): 45.

Intra-Community Transfers of Defence Products: Final Report. Brussels: European Commission, 2005.

Ismay, Lord Hastings. NATO's First Five Years. Paris: NATO, 1955.

Joffe, Josef. "Europe's American Pacifier." Foreign Policy 54 (1984): 64-82.

Jones, Robert. The Politics and Economics of the European Union. Cheltenham, U.K.: Edward Elgar Publishing Ltd., 1996.

Kagan, Robert. "France's Dream World." The Washington Post (2002): B07.

Kaufman, Richard. Privatization in North-Atlantic Cooperation Council Countries Colloquium 1994. Brussels, 1994.

Kirkpatrick, David. "The Rising Unit Cost of Defence Equipment-The Reasons and The Results." Defence and Peace Economics 6 (1995): 263-88.

Kirkpatrick, David. "Trends in the Costs of Weapon Systems and the Consequences." Defence and Peace Economics 15, no. 3 (2004): 259-73.

Klepsch, Egon. Report on European Armaments Procurement Cooperation In European Parliament Working Group., 1978.

Konver II-Fostering of Conversion by the European Union. Bonn: Bonn International Center for Conversion (BICC), 1997.

Le Blanc, Gilles. "Dépenses Militaires, Restructuration de l'Industrie d'Armement et Privatisation de la Défense: Analyse Comparée France-États-Unis 1994-1999." Arès 28, no. 46 (2000): 48.

Leonard, Dick. Guide to the European Union. 4th ed. London: The Economist, 1994.

Levi, Jean-Daniel, and Hughes Verdier. De L'Arsenal à L'Entreprise. Paris: Albin Michel, 2004.

Lieshout, Robert, Mathieu Segers, and Anna Vleuten. "De Gaulle, Moravcsik, and The Choice for Europe: Soft Sources, Weak Evidence." Journal of Cold War Studies 6, no. 4 (2004): 89-139.

Lindström, Gustav. Enter the EU Battlegroups In Chaillot Paper. Paris: WEU-ISS, 2007. 
Lipson, Michael. "The Reincarnation of COCOM: Explaining Post-Cold War Export Controls." The Non-Proliferation Review (1999): 33-51.

Litterick, David. Pentagon Awards Air Tanker Contract to EADS. telegraph.co.uk, 2008 .

Livre Blanc de la Défense. Paris: La Documentation Française, 1994.

Logsdon, Deborah. European Community Defense Industries: Threat to U.S. Competitiveness?. Washington, D.C.: The Industrial College of the Armed Forces, National Defense University, 1993.

Lovering, John. "Rebuilding the European Defence Industry in a Competitive World: Intergovernmentalism and the Leading Role Played by Companies." In Restructuring the Global Military Sector: The End of Military Fordism, 225-27. Vol. II. London: Pinter, 1998.

Masson, Axelle. "Le Cadre Institutionnel de la Coopération en Matière d'Armement en Europe." In Historie de la Coopération Européenne dans L'Armement, 194-95. Paris: CNRS Éditions, 2004.

McNamara, Robert S.. "The Military Role of Nuclear Weapons: Perceptions and Misperceptions." Foreign Affairs 62, no. 1 (1983): 59-80.

Mitrany, David. A Working Peace System. Chicago: Quadrangle Books, 1943.

Moravcsik, Andrew. De Gaulle and Europe: Historical Revision and Social Science Theory In Working Paper Series. Harvard University, Center for European Studies, 1998.

Olson, Mancur. The Logic of Collective Action: Public Good and the Theory of Groups. Cambridge, MA: Harvard University Press, 1965.

Peyrefitte, Alan. C'était de Gaulle. Vol. 3. Paris: Éditions de Fallois-Fayard, 2000.

Pommerin, Reiner. "Le Transall C 160. L'Histoire d'une 'Bête de Somme'." In Historie de la Coopération Européenne dans L'Armement, 45-53. Paris: CNRS Éditions, 2004.

Poniatowski, Axel. Pourquoi les Français et les Américains ne se Comprennent Plus. Paris: Perrin, 2004.

Prior Notification of a Concentration (Case COMP/M.4191 - État FrançaisThalès/DCN). European Commission (ECom), 2007.

Pugh, Philip. "The Procurement Nexus." Defence Economics 4 (1993): 179-94.

Robertson, George. NATO Needs New Forces for New Challenges. The Independent (U.K.), 2000. 


\section{THE QUARTERLY JOURNAL}

Sandler, Todd, and Keith Hartley. The Political Economy of NATO. Cambridge: Cambridge University Press, 1999.

Sapolsky, Harvey, and Eugene Gholz. "Restructuring the U.S. Defense Industry." International Security 24, no. 3 (1999): 5.

Schmitt, Burkhard. From Cooperation to Integration: Defence and Aerospace Industries in Europe In Chaillot Paper. Paris: WEU-ISS, 2000.

Schmitt, Hans. The Path to European Union: From the Marshall Plan to the Common Market. Baton Rouge: Louisiana State University Press, 1962.

Sköns, Elisabeth, and Richard Weidacher. Arms Production In SIPRI Yearbook 2002. Oxford: Oxford University Press, 2002.

Thatcher, Margaret. Statecraft: Strategies for a Changing World. New York: HarperCollins Publishers, 2002.

The Challenges Facing the European Defence-Related Industry: A Contribution for Action at European Level. European Commission (ECom), 1996.

The Gap in Defence Research and Technology Between Europe and the US In Assembly of the WEU. Paris: WEU, 2000.

Tindemans, Leo. L'Union Européenne. Rapport de M.Leo Tindemans au Conseil Européen In Bulletin des Communautés Européennes, Supplément. Commission des Communautés Européennes.

Urwin, Derek. The Community of Europe: A History of European Integration Since 1945. London: Longman Group, 1991.

Van Ham, Peter. Europe's New Defense Ambitions: Implications for NATO, the U.S. and Russia In The Marshall Center Papers. Garmisch-Partenkirchen: George C. Marshall European Center for Security Studies, 2000.

Vlachos-Dengler, Katia. From National Champions to European Heavyweights: The Development of European Defense Industrial Capabilities Across Market Segments. Santa Monica, CA: RAND Corporation, 2002.

Weber, Max. Économie et Société. Paris: Pocket, 1995.

Wolf, Jr., Charles, and Benjamin Zycher. European Military Prospects, Economic Constraints, and the Rapid Reaction Force. Santa Monica, CA: RAND Corporation, 2001.

Yost, David. "The U.S.-European Capabilities Gap and the Prospects for ESDP." In Defending Europe: The EU, NATO and The Quest for European Autonomy, 86-93. New York: Palgrave-MacMillan, 2003. 
WINTER 2008

Zeckhauser, Richard. "An Economic Theory of Alliances." The Review of Economics and Statistics 48, no. 3 (1966): 266-79.

Zorgbibe, Charles. Histoire de la Construction Européenne. Paris: Presses Universitaires de France, 1997. 